\title{
Case study: Hydraulic modeling of runoff processes in Ghanaian inland valleys
}

\section{$\operatorname{AUTHOR}(S):$}

Unami, Koichi; Kawachi, Toshihiko; KranjacBerisavljevic, Gordana; Abagale, Felix Kofi; Maeda, Shigeya; Takeuchi, Junichiro

\section{CITATION:}

Unami, Koichi ... [et al]. Case study: Hydraulic modeling of runoff processes in Ghanaian inland valleys. Journal of Hydraulic Engineering 2009, 135(7): 539-553

\section{ISSUE DATE:}

2009-07

URL:

http://hdl.handle.net/2433/84831

\section{RIGHT:}

C 2009 ASCE. 許諾条件により本文は2009-10-01に公開.; この論文は出版 社版でありません。引用の際には出版社版をご確認ご利用ください。; This is not the published version. Please cite only the published version. 


\title{
Case Study: Hydraulic Modeling of Runoff Processes in Ghanaian Inland Valleys
}

\author{
Koichi Unami, Aff. M. ASCE ${ }^{1}$, Toshihiko Kawachi ${ }^{2}$, Gordana Kranjac-Berisavljevic ${ }^{3}$, \\ Felix Kofi Abagale ${ }^{4}$, Shigeya Maeda ${ }^{5}$ and Junichiro Takeuchi ${ }^{6}$
}

\begin{abstract}
Inland valleys of West Africa are strategic in terms of food security and poverty alleviation, but scientific studies on hydrologic processes happening in these environments have not been well documented. Modeling approaches presented in this paper are an attempt to comprehend better hydraulic phenomena occurring in inland valleys. An inland valley situated in Northern Region of Ghana is set as the study site. The inland valley comprises well-drained uplands and hydromorphic valley bottoms. There are several earthen dams across the valley bottoms, which are at the same time seasonal wetlands cultivated to rice during the rainy season. A finite volume model for the shallow water equations is developed to numerically simulate surface runoff flows in the valley bottoms during flood events. Innovation is necessitated to handle a series of different hydraulic phenomena. Flux splitting and data reconstruction techniques are used to achieve stable computation in the complex topography of the valley bottoms. Standard problems of oblique hydraulic jump and dam break flows are used to test the accuracy of the numerical model. The Manning's roughness coefficient is determined from calibration in another Ghanaian watershed located in Eastern Region. Using actually observed time series data of rainfall intensity, surface flows during the rainfall events are simulated in the computational domain representing the valley bottoms of the study area. Observed data of water levels in the dams are compared with predictions, and discrepancies between them are examined from the hydrological point of view. In the case of a hypothetical flood event, cascading collapses of the dams and flooding of cultivated fields are reproduced.
\end{abstract}

\section{Introduction}

The small inland valleys are a significant feature of the topography of West African savannas, which extend between semi-arid Sahel and tropical rainforests in Sub-Saharan Africa. The

\footnotetext{
${ }^{1}$ Associate Professor, Graduate School of Agriculture, Kyoto University, Sakyo-ku, Kyoto, 606-8502 Japan.

${ }^{2}$ Professor, Graduate School of Agriculture, Kyoto University, Sakyo-ku, Kyoto, 606-8502 Japan.

${ }^{3}$ Associate Professor, Faculty of Agriculture, University for Development Studies, Tamale, Ghana.

${ }^{4}$ Senior Research Assistant, Faculty of Agriculture, University for Development Studies, Tamale, Ghana.

${ }^{5}$ Lecturer, Graduate School of Agriculture, Kyoto University, Sakyo-ku, Kyoto, 606-8502 Japan.

${ }^{6}$ Assistant Professor, Graduate School of Agriculture, Kyoto University, Sakyo-ku, Kyoto, 606-8502 Japan.
} 
Inland Valley Consortium (IVC) defines inland valleys in general as the upper reaches of river systems, in which river alluvial sedimentation processes are completely or almost absent (IVC 2007). The inland valleys, situated inland away from the main rivers and main tributaries, cover about $8 \%$ of the land area in Sub-Saharan Africa and are strategic in terms of food security and poverty alleviation. The International Institute for Land Reclamation and Improvement (ILRI) states that inland valleys appear to have a high potential for the development of rice-based smallholder farming systems at village scale, without major inputs (ILRI, 1993). In Ghana, gently sloping inland valleys are extensively found in Northern Region, whose largest sector of economy is subsistence agriculture. The Region is one of the poorest parts of the nation, suffering adverse effects of water scarcity, floods, water-borne diseases (Bierlich 1995; Kleinschmidt et al. 2001), and soil degradation (Braimoh and Vlek 2004). In fact, the prolonged severe effects of the floods that have occurred in the latter part of 2007 are being reported (OCHA 2007). The floods caused the destruction of bridges, roads, dams, and cropped farms.

Few scientific studies on hydrologic processes in West African inland valleys have been carried out so far. Casenave and Valentin (1992) analyze the factors influencing infiltration and runoff in various francophone West African countries. They emphasize important roles that surface features of soil play. Masiyandima et al. (2003) have conducted field research including rainfall and shallow groundwater analyses in an experimental watershed for two rainy seasons. Giertz et al. (2006) apply physically-based models to water balance analysis in a headwater catchment in central Benin. However, surface runoff processes in a single rainfall event have been least discussed in relation to hydraulic modeling (Chevallier and Planchon 1993). The kinematic method, which van de Giesen et al. (2005) apply to overland flows, cannot deal with complex hydraulic phenomena such as the backwater effect from a dam. On the other hand, the shallow water equations (SWEs), which are the full hydrodynamic equations, are proving their ability to reproduce overland flows when properly solved. Esteves et al. (2000) compare numerical results using a finite difference model with experimental results observed in a small Nigerien plot of $14.25 \mathrm{~m} \times 5.00 \mathrm{~m}$. Ajayi et al. (2008) apply similar methodology to experimental plots situated in the Ghanaian deciduous forest zone.

In this context, an inland valley is chosen as a study site in Tolon/Kumbungu District, Northern Region of Ghana, emphasizing hydraulic analysis of floods occurring within a single rainfall event. Nevertheless, data of several items such as rainfall and soil moisture are perennially collected to grasp hydrological basics of the study site. Then, numerical simulation of floods is implemented mainly based on the SWEs.

The SWEs model hydrodynamics of surface water flowing predominantly in the horizontal directions, and they are applicable to a broad range of practical problems where transcritical 
flows and abrupt changes in water depths may occur. The finite volume method is widely adopted as the framework for developing numerical schemes conserving mass and momentum, and it often considers a Riemann problem, which is an initial value problem whose initial condition is constant over each side of a straight line where a discontinuity occurs. Toro and Garcia-Navarro (2007) give a comprehensive review of Godunov-type schemes applied to SWEs. Zhao et al. (1996) compare performance of flux vector splitting, flux difference splitting, and Osher schemes, which are three different approximate Riemann solvers, and they conclude that all of the three schemes can satisfactorily solve hydraulic shock wave problems. Total variation diminishing (TVD) properties ensure that the summation of variations between the states at adjacent cells does not increase with time (Delis and Skeels 1998). Coupling a TVD scheme with a Riemann solver has drawn attention, as a prerequisite for resolving discontinuities and for obtaining high-order accuracy. Anastasiou and Chan (1997) developed a TVD solver implemented on unstructured triangular meshes for application to complex twodimensional (2D) channel bathymetry. Sleigh et al. (1998) further presented an algorithm that dealt with wetting and drying processes and applied it to estuarine flows. A refined model by Namin et al. (2004) simulated very detailed estuarine flows.

There are practical situations that require fundamental measures to treat the SWEs' source term, which is amplified when the channel bottom becomes steep and rough. Begnudelli and Sanders (2007) proposed very sophisticated data reconstruction method for water surface elevations on quadrilateral grids. Zhou et al. (2001) demonstrated that their surface gradient method (SGM), significantly improves the accuracy and stability of a Godunov-type scheme. Tseng (2004) and Mohamadian et al. (2005) successfully applied the SGM to more complex problems. When a special data reconstruction method such as the SGM is employed, however, the question whether solving a Riemann problem is reasonable arises. The assumption that the initial condition over each side of the straight line is constant is violated when the state is not reconstructed as a constant. Indeed, Yu and Liu (2001) presented a component-wise TVD finitedifference scheme not necessitating characteristic decompositions that are essential in approximate Riemann solvers. Lin et al. (2003) extended the component-wise TVD scheme to finite volume models with several splitting schemes. They concluded that the Liou-Steffen splitting (LSS) scheme (Liou and Steffen 1993) has the best performance.

The above-mentioned numerical models which have been developed so far, however, generally aim at analyzing open channel flows in an independent artificial hydraulic structure or natural water body and do not suit the requirement of operating the SWEs on the study site. Runoff processes in the study site, whose complex topography includes embankments of dams and roads, simultaneously involve wetting and drying, backwaters, dam breaches, and internal boundary conditions. The effect of numerical dissipation must be the minimum in order to 
reproduce correct magnitude of the surge causing cascading collapse of dams. Therefore, a novel numerical method for the SWEs is necessitated.

The authors are updating numerical models for the 2D SWEs with source terms to operate on unstructured triangular meshes. The earliest model (Unami et al. 1999) coupled the finite element method with the finite volume method. Then, Unami et al. (2006) proposed a pure finite volume scheme without using an approximate Riemann solver. An algebraic technique is utilized for reconstruction of water surface elevations within each cell, allowing for rapid variation in channel bed levels and very shallow water depths. The flux splitting scheme enhances the LSS scheme considering convective and pressure components. A simple procedure evaluating numerical fluxes on edges of cells from the split fluxes achieves monotonicity that satisfies a maximum principle on the discretized level as well as TVD properties, without introducing a diffusion term. Here, after verification using several test problems, the finite volume scheme is applied to hydraulic analysis of runoff processes in the study area.

\section{Description of Study Area}

\section{Northern Region of Ghana}

The Guinea savanna agro-ecological zone constitutes a strip between the equatorial forest zone and the Sudan savanna zone in West Africa and covers most part of Northern Region of Ghana. The annual rainfall pattern in the Guinea savanna agro-ecological zone is monomodal with the single rainy season from April to September, and thus the length of the growing period is 150180 days (Agyare et al. 2002). The mean annual rainfall in Tamale, the capital city of Northern Region, is about $1,050 \mathrm{~mm}$ (BBC Weather 2007). The problems of water scarcity are said to be increasing due to global desertification and climate change (Mwanza, 2003). Northern Region as a whole is also vulnerable to floods and water-borne diseases.

One of the characteristics of land use in Northern Region is intensive agricultural production in inland valleys (Dedzoe et al. 2002; Yiridoe et al. 2006). Inland valleys in Northern Region comprise well-drained uplands and hydromorphic valley bottoms. Traditionally, slash-and-burn farming system is established on the uplands, while the valley bottoms, which appear as wetlands during rainy seasons, are cultivated for rice production. There is a considerable pool of genetic diversity in crops, enabling robust production against climatic variability, pests, and diseases (Kranjac-Berisavljevic and Gandaa 2004; Tanzubil et al. 2004). Cattle, sheep, goats, and free-range guinea fowl are domestic animal and bird species commonly seen.

\section{Gbullung-West inland valley}


Bontanga River is one of the tributaries of White Volta and flows through Tolon/Kumbungu District of Northern Region. An inland valley, which is a sub-basin of the catchment basin of Bontanga River, is chosen as the study area and is referred to as the Gbullung-West (GbW) inland valley. Fig 1 locates the study area in the left panel with shading and describes its details in the right panel. It ranges from $092608 \mathrm{~N}$ to $092929 \mathrm{~N}$ in latitude, from $0010041 \mathrm{~W}$ to 001 $0345 \mathrm{~W}$ in longitude, and from EL129.3 m to EL182.9 m in altitude. Bontanga River has no perennial flow in the part forming the downstream boundary of the study area. The Bontanga Irrigation Project, expanding along the Bontanga River, is a gravity-fed irrigation project with a dam of about 20 million $\mathrm{m}^{3}$ storage capacity. However, the project is not benefiting the $\mathrm{GbW}$ inland valley. Therefore, rain-fed agriculture is the dominant activity for the inhabitants of the area. The soil of the uplands is classified as Dystric Plinthosols while that of the valley bottoms is Dystric Planosols (CERSGIS 2005). The upland soils are more gravelly around the ridges with steep slopes. On the other hand, vegetation including shrubs and groves is denser in the lower half of the GbW inland valley. Faculty of Agriculture, University for Development Studies (UDS), is situated in Nyankpala on the southern most ridge of the catchment basin of Bontanga River, as well as Savanna Agricultural Research Institute (SARI) and Animal Research Institute of the Council for Scientific and Industrial Research (CSIR).

Fig. 1. Catchment basin of Bontanga River and GbW inland valley

Geographical, infrastructural, and rural environmental data are collected from a sheet map (Survey of Ghana 1967), QuickBird satellite images with $0.6 \mathrm{~m}$ resolution, and field surveys conducted several times during 2005 through 2007. The valley bottoms can be identified from the satellite images as many rice threshing fields are found in them. Plane view of the inland valley with ground surface elevation of the valley bottoms is shown in Fig. 1. The total area is about $6.44 \mathrm{~km}^{2}$. There are 6 earthen dams (Dams 0 through 5) constructed in 1990s across the valley bottoms, and four of them (Dams 2 through 5) are equipped with concrete spillways. The widths of the concrete spillways are 24.5 m, 15.0 m, $20.2 \mathrm{~m}$, and $14.7 \mathrm{~m}$ for Dam 2, Dam3, Dam 4, and Dam 5, respectively. Dam 0 and Dam 1 are rather simple dug-outs. The embankment of Dam 0 is so rough that a part of it is eroded and sinks to serve as a spillway. An intake pipe is installed across the body of Dam 1 to supply water to troughs for animals, while excess water spills from the both upstream ends of the embankment. Rural communities, with names mentioned in Fig. 1, are situated in uplands, and most of the residents are subsistence farmers. The water stored in the dams is primarily used for domestic purposes in the neighboring communities. However, drinking water directly from the dams is not recommended since pollution due to the animals is serious and possibility of being infected with water-borne diseases such as dracunculiasis (guinea worm) is still high. Fetching water from the dug wells 
that are scattered in the valley bottoms is more hygienic, but these often dry up in dry season. The dams are also expected to raise groundwater levels so as to retard depletion of water in the dug wells. On the other hand, construction of the dams results in creation of backwater areas sacrificing the rice fields in the valley bottoms. Water from these dams is not used for irrigation purposes with a few exceptions of vegetable gardening. Minor fishery is also practiced in the dams as well as in Bontanga River. Feeder roads are embanked across the valley bottoms, and culverts of circular or rectangular cross sections are installed beneath the roads to avoid inundation. Locations of the culverts are marked with their shapes of cross sections in Fig. 1. However, seven culverts are closely clustered along the road crossing the $\mathrm{GbW}$ inland valley near the downstream side of Dam 0. Thus, comprehending the processes of rainwater harvesting at the dams, flooding of the rice fields, and possible breaching of the dams is of a significant concern for the study area and its inhabitants.

\section{Observation facilities}

Data on the rainfall intensity $r$ and the volumetric water content $\theta$ of soil are being collected at several observation sites around the study area. Raingauges (RGs) are of $0.2 \mathrm{~mm}$ tipping bucket type and are connected to pulse loggers so that $r$ in the period $P \mathrm{~s}$ between contiguous two pulses are obtained as $r=2 \times 10^{-4} / P \mathrm{~m} / \mathrm{s}$. Using soil moisture sensors with data loggers, values of $\theta$ are automatically recorded every hour on the hour. There are four observation sites which are referred to as NE, NW, GU, and GI sites, as dotted in Fig. 1. NE and NW sites are located in the eastern and western experimental fields of UDS, respectively. GU and GI sites are located near Gung and Gizaa communities, respectively. The wall of Dam 3 is located about $100 \mathrm{~m}$ downstream of the GI site. RGs are set at NE, NW, and GU sites. At NW site, two soil moisture sensors are set at the depths of $15 \mathrm{~cm}$ and $35 \mathrm{~cm}$. Another soil moisture sensor is set at the depth of $40 \mathrm{~cm}$ at GI site.

\section{Subsurface hydrology}

Subsurface flow regimes near the ground surface of the inland valley are inferred from observed data. Fig. 2 shows accumulated rainfall depth and $\theta$ observed at the upland NW site in year 2007. In the first half of the rainy season up to July, rainwater moistened the soil at the depth of $15 \mathrm{~cm}$ but scarcely reached to the depth of $35 \mathrm{~cm}$. This indicates that groundwater is not supplied from the uplands to the valley bottoms. In the second half of the rainy season from August, however, the soil moistures at both depths synchronized, suggesting that vertically infiltrated rainwater recharged the unconfined aquifer. A part of recharged groundwater in the unconfined aquifer of the uplands flows horizontally until seeping up to the ground surface of the valley bottoms. 
Fig. 2. Data observed at NW site in year 2007

\section{Simulation of Surface Water Flows Using Two-Dimensional Shallow Water Equations}

\section{Governing equations system}

The 2D SWEs represent conservation laws of mass and horizontal momentum and are written in the vector form as

$\frac{\partial \mathbf{U}}{\partial t}+\frac{\partial \mathbf{F}}{\partial x}+\frac{\partial \mathbf{G}}{\partial y}=\mathbf{S}$

where the $x-y-z$ Cartesian coordinates are taken so that z-axis is vertically upward, $t$ is the time, $\mathbf{U}$ the state vector, $\mathbf{F}$ and $\mathbf{G}$ the flux vectors, and $\mathbf{S}$ is the source term. The state vector is

$\mathbf{U}=\left(\begin{array}{l}U_{0} \\ U_{1} \\ U_{2}\end{array}\right)=\left(\begin{array}{l}h \\ p \\ q\end{array}\right)$

where $h$ is the water depth, $p$ and $q$ are the unit width discharges in $x$ and $y$ directions, respectively. The flux vectors are

$$
\mathbf{F}=\left(\begin{array}{c}
F_{0} \\
F_{1} \\
F_{2}
\end{array}\right)=\left(\begin{array}{c}
p \\
\frac{p^{2}}{h}+\frac{g h^{2}}{2} \\
\frac{p q}{h}
\end{array}\right), \quad \mathbf{G}=\left(\begin{array}{c}
G_{0} \\
G_{1} \\
G_{2}
\end{array}\right)=\left(\begin{array}{c}
q \\
\frac{p q}{h} \\
\frac{q^{2}}{h}+\frac{g h^{2}}{2}
\end{array}\right)
$$

where $g$ is the acceleration due to gravity. The source term is

$$
\mathbf{S}=\left(\begin{array}{c}
S_{0} \\
S_{1} \\
S_{2}
\end{array}\right)=\left(\begin{array}{c}
r_{e}+q_{s} \\
-g h \frac{\partial z_{b}}{\partial x}-g h \frac{n^{2} p \sqrt{p^{2}+q^{2}}}{h^{10 / 3}} \\
-g h \frac{\partial z_{b}}{\partial y}-g h \frac{n^{2} q \sqrt{p^{2}+q^{2}}}{h^{10 / 3}}
\end{array}\right)
$$


where $n$ is the Manning's roughness coefficient, $r_{e}$ the effective rainfall intensity, $q_{s}$ the seepage flow rate per unit area, and $z_{b}$ is the ground surface elevation.

\section{Finite volume model}

Computational procedures are constructed so as to be carried out over unstructured meshes consisting of triangular cells. The three vertices of each cell are counter-clockwise indexed as 0 , 1, and 2. Discretization of Eq. (1) in the spatial domain is based on the finite volume formulation

$$
\frac{d}{d t} \int_{\Omega_{i}} \mathbf{U} d \Omega_{i}+\int_{\Gamma_{i}}\left(\mathbf{F} n_{x}+\mathbf{G} n_{y}\right) d \Gamma_{i}=\int_{\Omega_{i}} \mathbf{S} d \Omega_{i}
$$

where $\Omega_{i}$ is the domain of the $i$ th cell, $\Gamma_{i}$ the boundary of $\Omega_{i}$, and $\left(n_{x}, n_{y}\right)^{T}$ is the outward unit normal vector on $\Gamma_{i}$. Notations $\mathbf{U}_{i}=\left(U_{0 i}, U_{1 i}, U_{2 i}\right)^{T}=\left(h_{i}, p_{i}, q_{i}\right)^{T}$ are introduced to represent the state vector and its components attributed to the $i$ th cell. Then, Eq. (5) is further arranged as the ordinary differential equation

$$
\frac{d \mathbf{U}_{i}}{d t}=-\frac{1}{A_{i}} \int_{\Gamma_{i}}\left(\mathbf{F} n_{x}+\mathbf{G} n_{y}\right) d \Gamma_{i}+\mathbf{S}_{i}
$$

where $A_{i}$ is the area of the $i$ th cell, and $\mathbf{S}_{i}$ is the source term $\mathbf{S}$ evaluated in the $i$ th cell. The boundary integral $\int_{\Gamma_{i}}\left(\mathbf{F} n_{x}+\mathbf{G} n_{y}\right) d \Gamma_{i}$ is the sum of the integrals along the three edges of the $i$ th cell. Therefore, developing a numerical model focuses on evaluation of the flux $\mathbf{F} n_{x}+\mathbf{G} n_{y}$ along the boundary of each cell as well as treatment of the source term $\mathbf{S}$ within each cell.

Firstly, a special technique is employed for reconstructing water surface elevations to deal with a wide range of water depths. The cell uniform depth $h_{0}$ is defined as

$h_{0}=\left\{\frac{n^{2}\left(p_{i}^{2}+q_{i}^{2}\right)}{I}\right\}^{\frac{3}{10}}$ 
where $I$ is the channel bed slope $\sqrt{\left(\frac{\partial z_{b}}{\partial x}\right)^{2}+\left(\frac{\partial z_{b}}{\partial y}\right)^{2}}$ in the cell. Using this $h_{0}$ as a criterion, the water surface elevation $\eta_{i s}$ at the $s$ th vertex of the $i$ th cell is reconstructed as

$$
\eta_{i s}=\omega\left(z_{i s}+h_{i}\right)+(1-\omega)\left(z_{i}+h_{i}\right)
$$

where $z_{i s}$ is $z_{b}$ at the sth vertex of the $i$ th cell, $z_{i}$ is the average of $z_{i s}$ for $s=0,1$, and 2 , and $\omega$ is the interpolation parameter, which is set as

$\omega=\max \left(\min \left(\frac{\delta z+h_{0}-h_{i}}{\delta z}, 1\right), 0\right)$

where $\delta z=\max \left(z_{i 0}, z_{i 1}, z_{i 2}\right)-z_{i}$. The water depth $h_{i s}$ at the $s$ th vertex of the $i$ th cell is obtained as $\eta_{i s}-z_{i s}$.

Next, a flux splitting scheme similar to the LSS scheme is applied for evaluating the flux on the edge that two cells share to fulfill the TVD properties. Details are described in Appendix I. The TVD scheme, which does not necessitate the characteristic decompositions, refers to the state vectors in the adjacent two cells only without using any extrapolation, so that the flux values in those cells bound those evaluated on the edge. Therefore, the finite volume formulation Eq. (5) remains consistent with Eq. (1) as the meshes are refined. An upwind scheme operated on the reconstructed water surface levels determines the values of $\mathbf{S}_{i}$. The temporal integration is performed using the 4 th order Runge-Kutta method with a specified time-step $\Delta t$. However, when the water depth in a cell falls below $\varepsilon=1.81 \times 10^{-5} \mathrm{~m}$, it is replaced by $\varepsilon$ in every calculation of the right hand side of Eq. (6). Furthermore, if the revised water depth after the temporal integration of $\Delta t$ is negative, then the unit width discharges are reset as 0 while the water depth is reset as the machine epsilon.

Two standard problems for horizontal and frictionless channels examine the performance of the scheme. A supercritical flow deflected by a converging wall forms an oblique hydraulic jump. The angle of shock front, or the Mach angle, is equal to $30^{\circ}$ when the upstream Froude number is equal to 2.74 for the channel with a converging angle of $8.95^{\circ}$. The upstream and the downstream water depths are 1.0 and 1.5 , respectively. The scheme easily achieves a steady numerical solution for the problem in a computational domain discretized into meshes with 2,400 cells, as shown in Fig. 3. The gray vertical plane in Fig. 3 delineates the analytical shock front, which is correctly reproduced in the numerical solution. There is no cell whose $h_{i}$ falls 
below 1.0, and it exceeds 1.5 in only few cells in the vicinity of the upstream end of the converging wall. This demonstrates monotonicity of the scheme.

Another problem is the $2 \mathrm{D}$ dam-break flow in a $200 \times 200$ square domain, which is separated by a dam wall along the $x=100$ line. The dam wall is partially breached at $95<y<170$ when $t$ $>0$. The initial still water depth is 10 for $x<100$ and is 5 for $x>100$. Fujihara and Borthwick (2000) develop a Godunov-type second-order accurate scheme, which yields the water depths at $t=7.2$ as shown in Fig. 4. The computational results by the current scheme are depicted in Fig. 5. Both are almost the same in terms of celerity, as the wave front, where the curvature in the $x$ direction along the center band $(130<y<135)$ of the bore vanishes, lies between $x=160$ and $x$ $=165$, but the effect of numerical dissipation is smaller in the current scheme.

Fig. 3. Perspective view of oblique hydraulic jump

Fig. 4. Perspective view of 2D dam-break flow at $t=7.2$ by Godunov-type scheme

Fig. 5. Perspective view of 2D dam-break flow at $t=7.2$ by proposed scheme

\section{Calibration in the catchment basin of a dam with concrete spillway}

The practical applicability of the numerical model is tested in another watershed to calibrate the Manning's roughness coefficient $n$. An earthen dam with a concrete spillway has been constructed at the coordinates $060607 \mathrm{~N}$ and $0000427 \mathrm{E}$ in the extension of Agricultural Research Centre (ARC)-Kpong, University of Ghana, which is situated in the coastal savanna agro-ecological zone (Kawachi et al. 2005). The catchment area of the dam is $1.16 \mathrm{~km}^{2}$ including the reservoir, and it is set as the computational domain. The ground surface elevations at several points in the domain are available from the survey results in 2001 and from the 1:50,000 map (Survey of Ghana 1974). Meshes consisting of 5,224 triangular cells are generated as shown in Fig. 6, and the resulting gradient of the ground surface level in the meshes varies from 1/9.68 to 1/1,270. A raingauge of the same type as in Northern Region is set at the position shown in Fig. 6. The spillway, whose location is also indicated in Fig. 6, is hydraulically regarded as a broad-crested weir, and its unit width discharge $q_{w}$ is assumed to be at a rate of

$q_{w}=0.326 \sqrt{2 g} H_{d}^{3 / 2}$ 
where $H_{d}$ is the overflow depth (Hager and Schwalt, 1994). This outflow discharge is specified as a boundary condition in the computation.

Fig. 6. Discretized domain of calibration watershed

The finite volume scheme with the time step $\Delta t=0.01 \mathrm{~s}$ is operated on the domain for a total period of 7 hours from the initial condition $\mathbf{U}=(0,0,0)^{T}$ at all the cells. No seepage flow is assumed, while rainfall intensity data, which was actually observed at the raingauge on April $1^{\text {st }}$, 2007, is employed as the input data. The total rainfall depth was $67.2 \mathrm{~mm}$. The hyetograph is shown in Fig. 7. Although the purpose of this test case is to calibrate the Manning's $n$ assumed constant in all the cells, the model also needs the effective rainfall intensity $r_{e}$ prescribed as a part of observed rainfall intensity. Here, a conceptual model determines $r_{e}$ from the observed time series data $r=r(t)$ as

$r_{e}=\min \left(1, \max \left(0, \frac{t-\tau-t_{\theta}}{\Theta}\right)\right) \max \left(0, r(t-\tau)-r_{\theta}\right)$

where $\tau, r_{\theta}, t_{\theta}$, and $\Theta$ are constant parameters, while $r_{e}=r$ is applied to the water surface of the reservoir when $h>\varepsilon$. The model is conceptual because the constant parameters have no direct meaning; nevertheless a hypothetical scenario might be given as follows. Rainwater reaches the surface of a shallow water body with $\tau$, the delay time, at an intensity of $r(t-\tau)$ exceeding $r_{\theta}$, the threshold rainfall intensity. However, this process starts only at $t_{\theta}$, the threshold time, and takes $\Theta$, the transient time, to completely develop. The parameters $r_{\theta}$ and $t_{\theta}$ are assumed to be 5 $\mathrm{mm} /$ hour and the time when the accumulated rainfall depth becomes $15 \mathrm{~mm}$, respectively. A trial-and-error method is applied to identify the other parameters $\tau$ and $\Theta$ as well as the Manning's $n$. Among different 14 combinations of the parameters within the ranges of 0.020 $0.070 \mathrm{~m}^{-1 / 3} / \mathrm{s}$ for $n, 1,200-1,600 \mathrm{~s}$ for $\tau$, and $700-1,600 \mathrm{~s}$ for $\Theta$, the set of $n=0.045 \mathrm{~m}^{-1 / 3} / \mathrm{s}, \tau=$ $1,260 \mathrm{~s}$, and $\Theta=1,080 \mathrm{~s}$ minimizes the maximum difference between the computed and observed water levels (WLs) as $2.04 \mathrm{~cm}$. The value of $n$ dominates the response characteristics of runoff; the larger the $n$, the larger the dissipation of flood waves. Fig. 7 charts computed WLs and overflow discharges with the observed WLs for the identified parameter values. Since a finite volume mesh cannot capture exact position of flow discontinuity, oscillations occur when much runoff water plunges into the reservoir. Nevertheless the flow field is globally stable, and the numerical model turns out to be robust.

Fig. 7. Hyetograph, dam water level, and overflow discharge from spillway

\section{Application to GbW inland valley}


The finite volume scheme is now applied for simulating surface flows in the GbW inland valley. The computational domain consists of the valley bottoms and is divided into unstructured triangular meshes with 7,590 cells and 4,467 nodes. Critical flow boundary conditions are imposed on the edges along the bank of Bontanga River, since the river bed is eroded almost vertically. Other boundary edges are regarded as wall boundaries. The hydraulic structures and the roads are treated as internal boundary conditions. For the culverts, the Manning's formula is employed to estimate the cross-sectional average velocity $V$ as

$V=\frac{1}{n_{c}} \sqrt{\|\nabla \eta\|} R^{2 / 3}$

where $n_{c}$ is the Manning's roughness coefficient for concrete, $R$ the hydraulic radius, and the water surface gradient $\nabla \eta$ is evaluated from $\eta$ of the adjacent two cells. The value of $n_{c}$ is assumed to be $0.015 \mathrm{~m}^{-1 / 3} \mathrm{~s}$. Eq. (10) for a broad-crested weir is applied to the spillways of the dams as well as the roads when water overflows them. Once the WL in the reservoir of a dam exceeds the top of the dam embankment, a part of the dam wall, which has been modeled as discontinuity of the computational domain, is instantaneously removed to represent the breach of dam. The part of breach is assumed to be around one the corners of embankment for each of Dam 2, Dam 3, Dam 4, and Dam 5, while no sudden breach is supposed for Dam 0 and Dam 1 which do not have concrete spillways.

The study area is so extensive that spatial distribution of the rainfall intensity has to be considered. Therefore the rainfall intensity $r$ is set at each of the three sites of GU, NW, and NE to constitute the rainfall intensity at each cell with weights proportional to the inverse squares of the distances.

Two cases of different conditions are considered. The first case simulates normal rainstorm events in the first half of the rainy season, while the second examines flood phenomena that occur in the second half of the rainy season. The valley bottoms are assumed to be saturated in the both cases, and effects of rainfall interception by vegetation are neglected. Therefore, a transformation procedure from the rainfall intensity into the effective rainfall intensity is not included.

The first case uses time series data of rainfall intensity $r$ actually observed in the period of 10 hours from 2:40 through 12:40 on May $14^{\text {th }}, 2007$, as the input to the numerical model. The total rainfall depth is $64.4 \mathrm{~mm}, 47.6 \mathrm{~mm}$, and $47.4 \mathrm{~mm}$ at GU, NW, and NE sites, respectively. Since crops are not planted in the valley bottoms in the early part of the rainy season, the Manning's $n$ 
is taken as $0.030 \mathrm{~m}^{-1 / 3} \mathrm{~s}$, which is a typical value for natural river beds. The seepage flow rate $q_{s}$ per unit area is assumed to be zero because groundwater is not supplied from the uplands to the valley bottoms. The time step $\Delta t$ is chosen equal to $0.005 \mathrm{~s}$. Computed and observed dam WLs are compared in Fig. 8, together with the hyetograph and the volumetric water content $\theta$ observed at GI site. The charts show rises in WLs from the initial time, using lines and circles for computed ones and observed ones, respectively. The rainwater flowing over ground surface is successfully harvested in the dams. Spillway overflow does not occur, both in the simulation and in reality. In Dam 1 and Dam 2 located in the lower half of the GbW inland valley, the observed WLs do not rise as high as the computes ones. Losses of rainfall due to infiltration and interception by vegetation seem to have effects. Situations are reversed in the WLs of Dam 4 and Dam 5, where the observed WLs start rising later but finally increase more than the computed WLs. Infiltration losses in the valley bottoms at the early stage before $t=1$ hour and considerable subsurface runoff from the uplands after that can explain the discrepancy. Indeed, the catchment areas of these dams are steep around the ridges and the upland soils are much more gravelly. Seemingly good agreement is obtained for Dam 3, but the assumptions of $r=r_{e}$ and $q_{s}=0$ is inconsistent with the downward infiltration as can be seen from non-decreasing observed $\theta$. A possible explanation is that subsurface runoff from the uplands cancels out infiltration losses in the valley bottoms. The computed WLs still increase even at the end of the period, while the observed WLs do not. This can be explained because the assumption of saturated surface soil is actually violated after stopping of rain. The computed flow field at the end of the period, when the runoff process is regarded as completed, is shown in Fig. 9. In this Figure as well as in Figs. 12 through 14 to be mentioned later, red arrows and yellow arrows for velocities represent supercritical and subcritical flows, respectively. Transcritical flows are reproduced in the vicinity of entrances of the dams.

Fig. 8. Results of observation and simulation for May 14, 2007

Fig. 9. Computed flow fields at $t=10$ hours when runoff process is completed

Next, the flood events which occurred in September, 2007, are considered. According to reports from the study area, floods followed the heavy and continuous rainfall until the dawn of September $6^{\text {th }}$. The water totally covered the rice fields around the site up to height of the crops, and farming activities were halted. The flooding lasted for about a month, including the whole month of September. The culverts linking the two communities of Gizaa and Jakpahi-Kukuo could not discharge the large volumes of water, which flowed over the road. Nevertheless, the communities situated on higher grounds of the uplands never experienced a flood. The dams succeeded in releasing all excess water through the spillways without breaching. 
The simulation period is taken as 6 hours from 21:00 on September $18^{\text {th }}$ through 3:00 on September $19^{\text {th }}$, when the study area has experienced the largest rainfall event since September $6^{\text {th }}$. There was a considerable rainfall from 19:30 to 20:00 on September $18^{\text {th }}$, preceding the main rainfall from 22:00 to 23:00 and minor peaks at midnight. The maximum rainfall intensity for the duration of 3 hours is $36.0 \mathrm{~mm} /$ hour, $26.6 \mathrm{~mm} /$ hour, and $26.2 \mathrm{~mm} /$ hour at GU, NW, and NE sites, respectively. The 10-year return period maximum rainfall intensity for the duration of 3 hours is $28.4 \mathrm{~mm} /$ hour in Tamale and is $34.5 \mathrm{~mm} /$ hour in Yendi, situated about $100 \mathrm{~km}$ east of Tamale (Dankwa, 1974). The seepage flow rate $q_{s}$ per unit area is computed as

$q_{s}=k_{H}\left(\frac{\partial \eta}{\partial x} \frac{\partial z_{b}}{\partial x}+\frac{\partial \eta}{\partial y} \frac{\partial z_{b}}{\partial y}\right)$

where $k_{H}$ is the hydraulic conductivity in horizontal directions, and $\eta$ is the water surface elevation. Eq.(13) is derived in Appendix II. Two runs, where the values of $k_{H}$ are $0.005 \mathrm{~m} / \mathrm{s}$ and $0.010 \mathrm{~m} / \mathrm{s}$, are implemented. The value of the Manning's $n=0.045 \mathrm{~m}^{-1 / 3} \mathrm{~s}$, as identified in ARCKpong, is common for the whole valley bottoms in the both runs. The time step $\Delta t$ is chosen equal to $0.005 \mathrm{~s}$. A steady flow state with $r=1 \mathrm{~mm} /$ hour and $k_{H}=0.001 \mathrm{~m} / \mathrm{s}$ is set as the initial condition, where the valve of the intake pipe of Dam 1 is open. This tests the effects of anticipating release of dam water in floods. In reality, water was full in Dam 1 for weeks after September $6^{\text {th }}$. At the initial time, the embankment of Dam 0 is assumed to collapse to block the sinking part. The valve of the intake pipe of Dam 1 is also closed. The spillways of Dam 2, Dam 3, Dam 4, and Dam 5 more or less release excess water. The hyetograph, $\theta$ observed at GI site, observed WLs of the Dams, and computed WLs of the dams are shown in Figs. 10 and 11 for the two runs. In those figures, the origin of the water height is taken at the dead-storage level, or the original ground height before embankment of the dam. The horizontal two lines for each dam represent the heights of the spillway crest and the top of the dam embankment.

In both runs, the computed WLs of Dam 0 and Dam 1 start increasing because of sudden blocking of the water exits. The absence of rainfall until $t=1$ hour brings about a decrease in the inflow discharge into Dam 0, and then a decrease in the WL after a peak follows. The WL of Dam 1 continues to increase because the initial WL, which is at the inlet of the intake pipe, is so low. In case where $k_{H}=0.005 \mathrm{~m} / \mathrm{s}$, the computed WLs of Dam 1 converge to the observed ones at $t=3$ hours, and good agreement continues until $t=6$ hours. The effect of anticipating operation of the valve is minor. Starting from the same initial value, the observed WLs and the computed WLs in Dam 2 agree well until $t=4$ hours. In Dam 3, the computed WL rises too early, and that is magnified when $k_{H}=0.010 \mathrm{~m} / \mathrm{s}$. Taking a smaller value for $k_{H}$ should result in better accordance before $t=3$ hours, but the discrepancy whould become larger after that. Unlike the case of May, the observed WLs in Dam 4 and Dam 5 increase as soon as rain starts 
to agree with the computed ones. However, after $t=2$ hours, the observed WLs in these dams increase drastically, representing considerable inflows probably due to subsurface runoff from the uplands. Such inflows that the numerical model cannot reproduce occur in the order of Dam 5, Dam 4, Dam 3 if the value of $k_{H}$ is taken smaller, and Dam 2. This is consistent with the scenario that subsurface runoff from the uplands occurs in the upper half of the GbW inland valley and propagates downstream.

The setting of $k_{H}=0.010 \mathrm{~m} / \mathrm{s}$ turns out to be excessive, and the run is regarded as testing a hypothetical flood event. The main phenomenon that the numerical model reproduces are cascading collapses of the dams and flooding of relevant valley bottoms. Firstly, breach of Dam 3 occurs at $t=4.14$ hours, resulting in a surge to bring about cascading collapse of Dam 2 at $t=$ 5.05 hours. The surge reaches to Dam 1 and then to Dam 0 at about $t=5.4$ hours and $t=5.8$ hours, respectively. Figs. 12, 13, and 14 delineate the computed flow fields every 40 minutes from $t=4$ hours. In this case, transcritical flows in the vicinity of entrances of the dams become minor in comparison with the case of May. Before the collapse of the dams, the release discharge from the spillway of Dam 3 is so large that the flow immediately downstream of the spillway is supercritical, as shown in Fig. 12. Some parts of the roads are inundated because capacity of the culverts is not sufficient. The backwaters from the embankments of the dams and the roads considerably affect the rice fields. Once Dam 3 collapses, the surge, which occasionally becomes supercritical as shown in Fig. 13, devastates the rice fields between Dam 3 and Dam 2. Vortices of high velocity appear in the vicinity of the part of breach. This situation is duplicated in the downstream after the breaching of Dam 2, as shown in Fig. 14.

Fig. 10. Results of observation and simulation with $k_{H}=0.005 \mathrm{~m} / \mathrm{s}$ for September 18-19, 2007

Fig. 11. Results of observation and simulation with $k_{H}=0.010 \mathrm{~m} / \mathrm{s}$ for September 18-19, 2007

Fig. 12. Computed flow fields at $t=4.00$ hours before breaching of dams

Fig. 13. Computed flow fields at $t=4.67$ hours when a surge propagating from Dam 3 to Dam 2

Fig. 14. Computed flow fields at $t=5.33$ hours after breaching of two dams

Some hydrological aspects that can be inversely inferred from the discrepancies between the computed and the observed results are summarized as follows. Infiltration takes place in the upper valley bottoms only in the first half of the rainy season. As has been done in ARC-Kpong, transformation from $r$ into $r_{e}$ is necessary for more precise reproduction of phenomena in the GbW inland valley. Considerable subsurface runoff occurs from the uplands in the catchment 
areas of Dam 4 and Dam 5, and it is harvested in those dams but propagates downstream when they are full.

\section{Conclusions}

The GbW inland valley has been chosen as the study area representing West African inland valleys, which are very strategic in terms of food security and poverty alleviation. Hydraulic modeling approaches are applied to examining the runoff processes in event-wise time scales. The finite volume model for the 2D SWEs is the main tool for analyzing surface water flows, and is capable of reproducing transcritical hydraulic phenomena. In application to runoff events, time series data of effective rainfall intensity are the only input to the model when it is run. The model parameter $n$ when the ground is grown with plants is decided according to the calibration in the other Ghanaian site of ARC-Kpong. The numerical experiments in the GbW inland valley assume that only direct rainfall and seepage out of the ground dominate surface water flows. The computational domain is limited to the valley bottoms. The rainfall data observed in May and September, 2007, are used as representatives of the first and the second half of the rainy season. The test case for hypothetical flood event demonstrates risk of cascading collapse of the dams and flooding of cultivated fields. Some hydrological aspects in the GbW inland valley are inversely inferred from the discrepancies occurring between the computed and the observed results.

In reality, the dams in the GbW inland valley did not collapse in the actual floods of September, 2007, since the rain was not so heavy as in Upper Regions of Ghana and Burkina Faso. However, the results of this study demonstrate that it might be catastrophic if $k_{H}$ were only doubled. The WLs of Dam 4 rose up to only $18 \mathrm{~cm}$ below the level of collapse. It is also imperative to identify appropriate farming activities to control subsurface flows as well as suitable rehabilitation works to be done the dams.

\section{Acknowledgements}

The writers thank Professor Masayuki Fujihara of College of Agriculture, Ehime University, Japan, for providing reference computational data. The staff of ARC-Kpong, headed by Dr. Macarius Yangyuoru, are greatly appreciated for their assistance in collecting the calibration data. This work is supported by the grants-in-aid No. 17688010 and No. 20255012 made by MEXT and JSPS, Japan.

\section{Appendix I: Details of flux splitting scheme}


Let $\Gamma(\neq \varnothing)$ be $\Gamma_{i} \cap \Gamma_{k}$, and let the $j$ th vertex of the $i$ th cell be not on $\Gamma$. The flux vectors on $\Gamma$ in the side of the $i$ th cell are splitted with a weight $w$ as

$\mathbf{F}_{i}=\left(\begin{array}{c}p_{i} \\ \frac{g h_{i \Gamma}^{2}}{2} \\ 0\end{array}\right)+\frac{1+w}{2}\left(\begin{array}{c}0 \\ \frac{p_{i}^{2}}{h_{i}} \\ \frac{p_{i} q_{i}}{h_{i}}\end{array}\right)+\frac{1-w}{2}\left(\begin{array}{c}0 \\ \frac{p_{k}^{2}}{h_{k}} \\ \frac{p_{k} q_{k}}{h_{k}}\end{array}\right)$

and

$\mathbf{G}_{i}=\left(\begin{array}{c}q_{i} \\ 0 \\ \frac{g h_{i \Gamma}^{2}}{2}\end{array}\right)+\frac{1+w}{2}\left(\begin{array}{c}0 \\ \frac{p_{i} q_{i}}{h_{i}} \\ \frac{q_{i}^{2}}{h_{i}}\end{array}\right)+\frac{1-w}{2}\left(\begin{array}{c}0 \\ \frac{p_{k} q_{k}}{h_{k}} \\ \frac{q_{k}^{2}}{h_{k}}\end{array}\right)$

where

$h_{i \Gamma}^{2}=\frac{h_{i j_{1}}^{2}+h_{i j_{1}} h_{i j_{2}}+h_{i j_{2}}^{2}}{3}$

where $j_{1}=\bmod (j+1,3)$, and $j_{2}=\bmod (j+1,2)$. Schematic sketch of local geometry is given in Fig.

18. The Froude number $F r_{i}$ in the normal direction of $\Gamma$ is defined as

$F r_{i}=\frac{p_{i} \Delta y-q_{i} \Delta x}{\sqrt{g h_{i}^{3}} \sqrt{\Delta x^{2}+\Delta y^{2}}}$

where $(\Delta x, \Delta y)^{T}$ is the vector originating at the $j_{1}$ th vertex and ending at the $j_{2}$ th vertex, and it serves as the weight $w$, which is determined by

$w=\max \left(\min \left(F r_{i}, 1\right),-1\right)$.

The flux vectors are integrated along $\Gamma$ as 
$\left(\begin{array}{c}\Phi_{0_{i}} \\ \Phi_{1_{i}} \\ \Phi_{2_{i}}\end{array}\right)=\mathbf{F}_{i} \Delta y-\mathbf{G}_{i} \Delta x$

to evaluate the numerical fluxes $\Phi_{m}(m=0,1$, and 2$)$ on $\Gamma$ as

$\Phi_{m}=\left\{\begin{array}{cc}\min \left(\Phi_{m_{i}},-\Phi_{m_{k}}\right), & \left(U_{m_{i}}<U_{m_{k}}\right) \\ \frac{\Phi_{m_{i}}-\Phi_{m_{k}}}{2}, & \left(U_{m_{i}}=U_{m_{k}}\right) \\ \max \left(\Phi_{m_{i}},-\Phi_{m_{k}}\right), & \left(U_{m_{i}}>U_{m_{k}}\right)\end{array}\right.$

but application of

$\Phi_{m}=\left\{\begin{array}{cc}\Phi_{m_{i}}, & \left(F r_{i}>1 \cap-F r_{k}>1\right) \\ -\Phi_{m_{k}}, & \left(F r_{i}<-1 \cap-F r_{k}<-1\right)\end{array}\right.$

takes priority for $m=1$ and 2. Finally,

$\int_{\Gamma}\left(\mathbf{F} n_{x}+\mathbf{G} n_{y}\right) d \Gamma_{i}=\left(\begin{array}{c}\Phi_{0} \\ \Phi_{1} \\ \Phi_{2}\end{array}\right)$

and

$\int_{\Gamma}\left(\mathbf{F} n_{x}+\mathbf{G} n_{y}\right) d \Gamma_{k}=-\left(\begin{array}{c}\Phi_{0} \\ \Phi_{1} \\ \Phi_{2}\end{array}\right)$

are employed in Eq. (6).

Fig. 15. Cells and vertices concerning flux splitting scheme

Appendix II: Derivation of seepage flow rate 
When the saturated soil of the valley bottoms is assumed to be horizontally homogeneous, the three-dimensional Darcy flux $\mathbf{q}_{D}$ becomes

$\mathbf{q}_{D}=-\left(\begin{array}{l}k_{H} \frac{\partial H}{\partial x} \\ k_{H} \frac{\partial H}{\partial y} \\ k_{V} \frac{\partial H}{\partial z}\end{array}\right)$

where $k_{V}$ is the hydraulic conductivity in vertical direction, and $H$ is the hydraulic head. If the ground surface is covered with surface water and the soil is saturated down to the impermeable layer, then the hydraulic head $H$ is equal to the water surface level $\eta$, which is constant with respect to $z$. Since the outward unit normal vector $\mathbf{n}$ on the ground surface is given by

$\mathbf{n}=\frac{1}{\sqrt{\left(\frac{\partial z_{b}}{\partial x}\right)^{2}+\left(\frac{\partial z_{b}}{\partial y}\right)^{2}+1}}\left(\begin{array}{c}-\frac{\partial z_{b}}{\partial x} \\ -\frac{\partial z_{b}}{\partial y} \\ 1\end{array}\right)$

seepage flow rate $q_{s}$ per unit area is deduced as

$q_{S}=\lim _{A_{S} \rightarrow 0} \frac{\int_{S} \mathbf{q}_{D} \cdot \mathbf{n} d S}{A_{S}}=k_{H}\left(\frac{\partial \eta}{\partial x} \frac{\partial z_{b}}{\partial x}+\frac{\partial \eta}{\partial y} \frac{\partial z_{b}}{\partial y}\right)$

where $S$ is the domain on the ground surface area, and $A_{S}$ is the area of the projection of $S$ to the $x-y$ plane.

\section{Notations}

The following symbols are used in this paper:

$A_{i}=$ area of the $i$ th cell;

$A_{S}=$ area of the projection of $S$ to the $x-y$ plane;

$\mathbf{F}=$ flux vector in $x$ direction;

$F_{i}=$ component of $\mathbf{F}$ for $i=0,1$, and 2 ;

$F r_{i}=$ Froude number in the normal direction of $\Gamma$ defined in the side of the $i$ th cell; 
$\mathbf{G}=$ flux vector in $y$ direction;

$G_{i}=$ component of $\mathbf{G}$ for $i=0,1$, and 2 ;

$g=$ acceleration due to gravity;

$H=$ hydraulic head;

$H_{d}=$ overflow depth of a broad crested weir;

$h=$ water depth;

$h_{0}=$ cell uniform depth;

$h_{i s}=$ water depth at the $s$ th vertex of the $i$ th cell;

$h_{i \Gamma}=$ water depth evaluated on $\Gamma$ in the side of the $i$ th cell;

$I=$ channel bed slope in the cell;

$j_{k}=$ vertex number which is equal to $\bmod (j+k, 3)$ for $k=1$ and 2 ;

$k_{H}=$ hydraulic conductivity in horizontal directions;

$k_{V}=$ hydraulic conductivity in vertical direction;

$n=$ Manning's roughness coefficient;

$\mathbf{n}=$ outward normal vector on the ground surface;

$n_{c}=$ Manning's roughness coefficient for concrete;

$\left(\begin{array}{l}n_{x} \\ n_{y}\end{array}\right)=$ outward unit vector on $\Gamma_{i}$;

$p=$ unit width discharge in $x$ direction;

$q=$ unit width discharge in $y$ direction;

$\boldsymbol{q}_{D}=$ three-dimensional Darcy flux;

$q_{s}=$ seepage flow rate per unit area;

$q_{w}=$ unit width discharge of a broad crested weir;

$R=$ hydraulic radius;

$r=$ rainfall intensity;

$r_{e}=$ effective rainfall intensity;

$r_{\theta}=$ constant parameter which might be threshold rainfall intensity;

$S=$ domain on the ground surface area;

$\mathbf{S}=$ source term;

$S_{i}=$ component of $\mathbf{S}$ for $i=0,1$, and 2 ;

$\mathbf{S}_{i}=\mathbf{S}$ evaluated in the $i$ th cell;

$t=$ time;

$t_{\theta}=$ constant parameter which might be threshold time;

$\mathbf{U}=$ state vector;

$U_{\boldsymbol{i}}=$ component of $\mathbf{U}$ for $i=0,1$, and 2 ;

$V=$ cross-sectional average velocity;

$w=$ weight;

$x=$ horizontal coordinate (eastward); 
$y=$ horizontal coordinate (northward);

$z=$ vertical coordinate (upward);

$z_{b}=$ ground surface elevation;

$z_{i}=$ average of $z_{i s}$ for $s=0,1$, and 2 ;

$z_{i s}=$ ground surface elevation at the $s$ th vertex of the $i$ th cell;

$\Gamma=$ intersection of the boundaries of two adjacent cells;

$\Gamma_{i}=$ boundary of $\Omega_{i}$;

$\Delta t=$ time step;

$\left(\begin{array}{l}\Delta x \\ \Delta y\end{array}\right)=$ vector originating at the $j_{1}$ th vertex and ending at the $j_{2}$ th vertex on $\Gamma$;

$\Delta \eta=$ water surface gradient;

$\delta z=\max \left(z_{i 0}, z_{i 1}, z_{i 2}\right)-z_{i}$;

$\varepsilon=$ minimum water depth in computation;

$\eta_{i s}=$ water surface elevation;

$\eta_{i s}=$ water surface elevation at the $s$ th vertex of the $i$ th cell;

$\Theta=$ constant parameter which might be transient time;

$\theta=$ volumetric water content of soil;

$\tau=$ constant parameter which might be delay time;

$\Phi_{m}=$ numerical flux evaluated on $\Gamma$ for $m=0,1$, and 2;

$\Phi_{m_{i}}=$ component of the flux vector integrated along $\Gamma$ in the side of the $i$ th cell for $m=0,1$, and 2 ;

$\Omega_{i}=$ domain of $i$ th cell; and

$\omega=$ interpolation parameter.

\section{Subscripts}

$i=$ value attributed to the $i$ th cell when used for the state vector and its components.

\section{References}

Agyare, W. A., Kombiok, J. M., Karbo, N., and Larbi, A. (2002). "Management of pigeon pea in short fallows for crop-livestock production systems in the Guinea savanna zone of northern Ghana". Agroforestry Systems, 54, 197-202.

Ajayi, A. E., van de Giesen, N., and Vlek, P. (2008). "A numerical model for simulating Hortonian overland flow on tropical hillslopes with vegetation elements". Hydrological Processes, 22(8), 1107-1118. 
Anastasiou, K., and Chan, C. T. (1997). "Solution of the 2D shallow water equations using the finite volume method on unstructured triangular meshes". International Journal for Numerical Methods in Fluids, 24, 1225-1245.

Begnudelli, L., and Sanders, B. F. (2007). "Conservative wetting and drying methodology for quadrilateral grid finite-volume models". Journal of Hydraulic Engineering, 133(3), 312-322.

Bierlich, B. (1995). "Notions and treatment of guinea worm in Northern Ghana". Social Science \& Medicine, 41(4), 501-509.

Braimoh, A. K., and Vlek, P. L. G. (2004). "The impact of land-cover change on soil properties in northern Ghana". Land Degradation \& Development, 15, 65-74.

British Broadcasting Corporation (BBC), (2002). "BBC Weather, Tamale, Ghana". http://www.bbc.co.uk/weather/world/city_guides/results.shtml?tt=TT000250 (Dec. 3, 2008).

Casenave, A., and Valentin, C. (1992). "A runoff capability classification system based on surface features criteria in semi-arid areas of West Africa". Journal of Hydrology, 130, 231-249.

Centre for Remote Sensing and Geographic Information Service (CERSGIS), 2005. "FAO soil classification map for SLaM study site in Fihini area". University of Ghana, Legon, Accra.

Chevallier, P., and Planchon, O. (1993). "Hydrological processes in a small humid savanna basin (Ivory Coast)". Journal of Hydrology, 151, 173-191.

Dankwa, J. B. (1974). "Maximum rainfall intensity-duration frequencies in Ghana". Ghana Meteorological Service Department, Department Note, 23, Accra.

Dedzoe, C. D., Senayah, J. K., Antwi, B. O., and Tetteh, F. M. (2002). "Environmental and socio-economic characteristics of the Kpene catchment in Northern Ghana: implications for soil and water conservation". Proceedings of the 12th International Soil Conservation (ISCO) Conference, Beijing, 182-186.

Delis, A. I., and Skeels, C. P. (1998). "TVD schemes for open channel flow". International Journal for Numerical Methods in Fluids, 26, 791-809. 
Esteves, M., Faucher, X., Galle, S., and Vauclin, M. (2000). "Overland flow and infiltration modelling for small plots during unsteady rain: numerical results versus observed values". Journal of Hydrology, 228, 265-282.

Fujihara, M., and Borthwick, A. G. L. (2000). "Godunov-type solution of curvilinear shallowwater equations". Journal of Hydraulic Engineering, 126(11), 827-836.

Giertz, S., Diekkrüger, B., and Steup, G. (2006). "Physically-based modelling of hydrological processes in a tropical headwater catchment (West Africa) - process representation and multicriteria validation". Hydrology and Earth System Sciences, 10, 829-847.

Hager, W. H., and Schwalt, M. (1994). "Broad-crested weir". Journal of Irrigation and Drainage Engineering, 120(1), 13-26.

International Institute for Land Reclamation and Improvement (ILRI), (1993). "Inland valleys in West Africa: An agro-ecological characterization of rice-growing environments". ILRI Publication, 52, Windmeijer, P. N. and Andriesse, W. (Eds), 11 .

Inland Valley Consorthium (IVC), (2007). "Inland valleys". http://www.warda.cgiar.org/ivccbf/ (Dec. 3, 2008).

Kawachi, T., Aoyama, S., Yangyuoru, M., Unami, K., Matoh, T., Acquah, D., and Quarshie, S. (2005). "An irrigation tank for harvesting rainwater in semi-arid savannah areas". Journal of Rainwater Catchment Systems, 11(1), 17-24.

Kleinschmidt, I., Omumbo, J., Briët, O., van de Giesen, N., Sogoba, N., Mensah, N. K., Windmeijer, P., Moussa, M., and Teuscher, T. (2001). “An empirical malaria distribution map for West Africa". Tropical Medicine and International Health, 6(10), 779-786.

Kranjac-Berisavljevic, G., and Gandaa, B. Z. (2004). "Sustaining diversity of yams in northern Ghana". Managing Agrodiversity the Traditional Way: Lessons from West Africa in Sustainable Use of Biodiversity and Related Natural Resources, United Nations University Press, 84-96.

Lin, G.-F., Lai, J.-S., and Guo, W.-D. (2003). "Finite-volume component-wise TVD schemes for 2D shallow water equations". Advances in Water Resources, 26, 861-873.

Liou, M.-S., and Steffen, Jr., C. J. (1993). "A new flux splitting scheme". Journal of Computational Physics, 107, 23-39. 
Masiyandima, M. C., van de Giesen, N., Diatta, S., Windmeijer, P. N., and Steenhuis, T. S. (2003). "The hydrology of inland valleys in the sub-humid zone of West Africa: rainfall-runoff processes in the M'bé experimental watershed". Hydrological Processes, 17, 1213-1225.

Mohamadian, A., Le Roux, D. Y., Tajrishi, M., and Mazaheri, K. (2005). "A mass conservative scheme for simulating shallow flows over variable topographies using unstructured grid". Advances in Water Resources, 28, 523-539.

Mwanza, D. D. (2003). "Water for sustainable development in Africa." Environment, Development and Sustainability, 5, 95-115.

Namin, M., Lin, B., and Falconer, R. A. (2004). "Modelling estuarine and coastal flows using an unstructured triangular finite volume algorithm". Advances in Water Resources, 27, 11791197.

Office for the Coordination of Humanitarian Affairs (OCHA), (2007). "Ghana floods flash appeal 2007". http://ochaonline.un.org/humanitarianappeal/webpage.asp?Page=1620 (Dec. 3, 2008).

Sleigh, P. A., Gaskell, P. H., Berzins, M., and Wright, N. G. (1998). "An unstructured finitevolume algorithm for predicting flow in rivers and estuaries". Computers \& Fluids, 27(4), 479508 .

Survey of Ghana. (1967). 1:50,000 map, Sheet 0902D2.

Survey of Ghana. (1974). 1:50,000 map, Sheet 0600C3.

Tanzubil, P. B., Dittoh, J. S., and Kranjac-Berisavljevic, G. (2004). "Conservation of indigenous rice varieties by women of Gore in the northern savanna zone, Ghana". Managing Agrodiversity the Traditional Way, United Nations University Press, Tokyo, 97-105.

Toro, E. F., and Garcia-Navarro, P. (2007). "Godunov-type methods for free-surface shallow flows: A review". Journal of Hydraulic Research, 45(6), 736-751.

Tseng, M.-H. (2004). "Improved treatment of source terms in TVD scheme for shallow water equations". Advances in Water Resources, 27, 617-629. 
Unami, K., Kawachi, T., Babar, M. M., and Itagaki, H. (1999). "Two-dimensional numerical model of spillway flow". Journal of Hydraulic Engineering, 125(4), 369-375.

Unami, K., Kawachi, T., Yangyuoru, M., and Ishida, K. (2006). "A finite volume scheme for simulation of rainwater harvesting process". Proc. of the $2^{\text {nd }}$ IASTED Int. Conf. on Advanced Technology in the Environmental Field, Lanzarote, 124-129.

van de Giesen, N., Stomph, T. J., de Ridder, N. (2005). "Surface runoff scale effects in West African watersheds: Modeling and management options". Agricultural Water Management, 72(2), 109-130.

Yiridoe, E. K., Langyintuo A. S., and Dogbe, W. (2006). "Economics of the impact of alternative rice cropping systems on subsistence farming: Whole-farm analysis in northern Ghana”. Agricultural Systems, 91, 102-121.

Yu, H., and Liu, Y.-P. (2001). "A second-order accurate, component-wise TVD scheme for nonlinear, hyperbolic conservation laws". Journal of Computational Physics, 173, 1-16.

Zhao, D. H., Shen, H. W., Lai, J. S., and Tabios III, G. Q. (1996). "Approximate Riemann solvers in FVM for 2D hydraulic shock wave modeling". Journal of Hydraulic Engineering, 122(12), 692-702.

Zhou, J. G., Causon, D. M., Mingham, C. G., and Ingram, D. M. (2001). "The surface gradient method for the treatment of source terms in the shallow water equations". Journal of Computational Physics, 168, 1-25. 


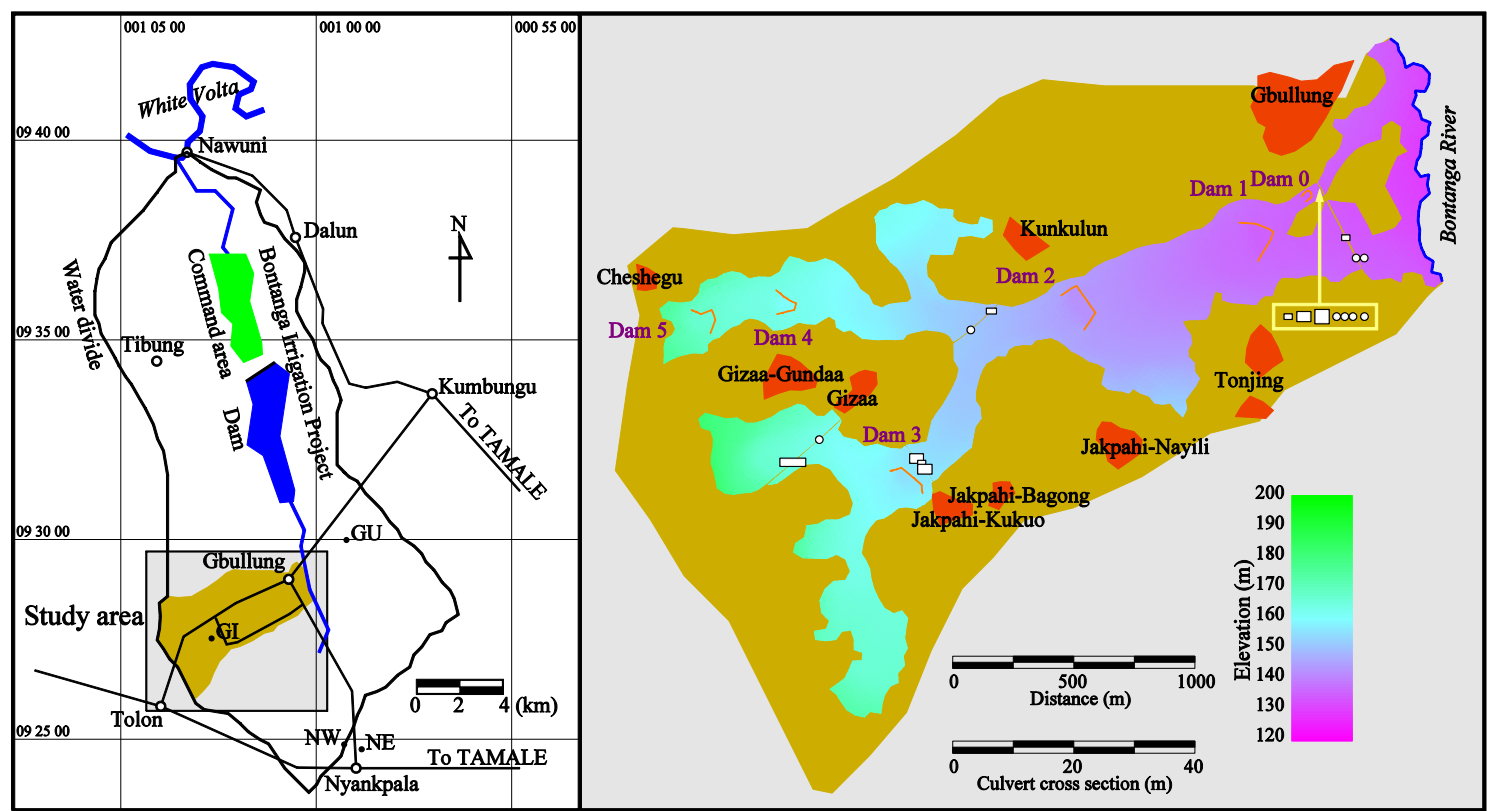

Fig. 1. Catchment basin of Bontanga River and GbW inland valley 


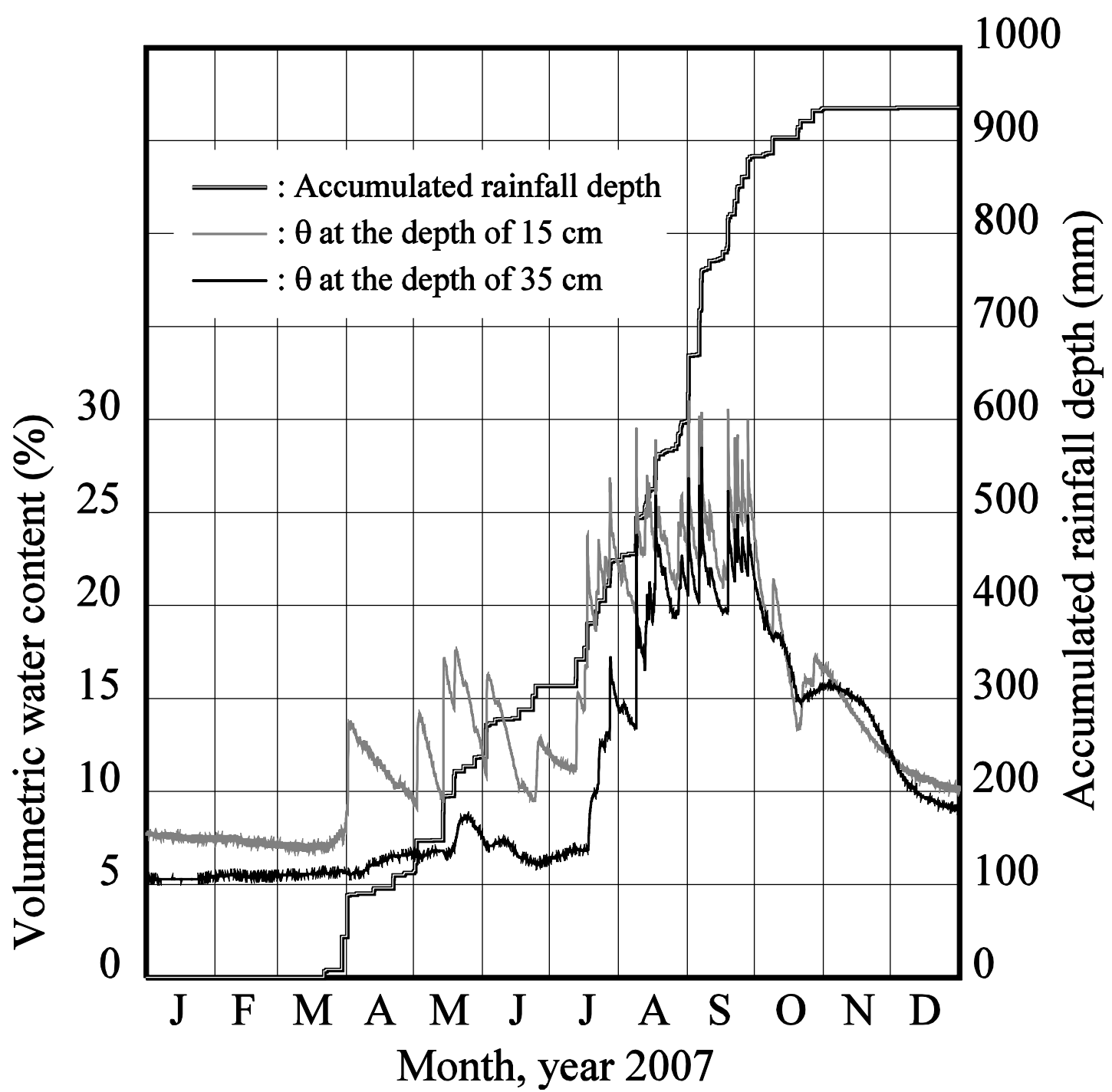

Fig. 2. Data observed at NW site in year 2007 


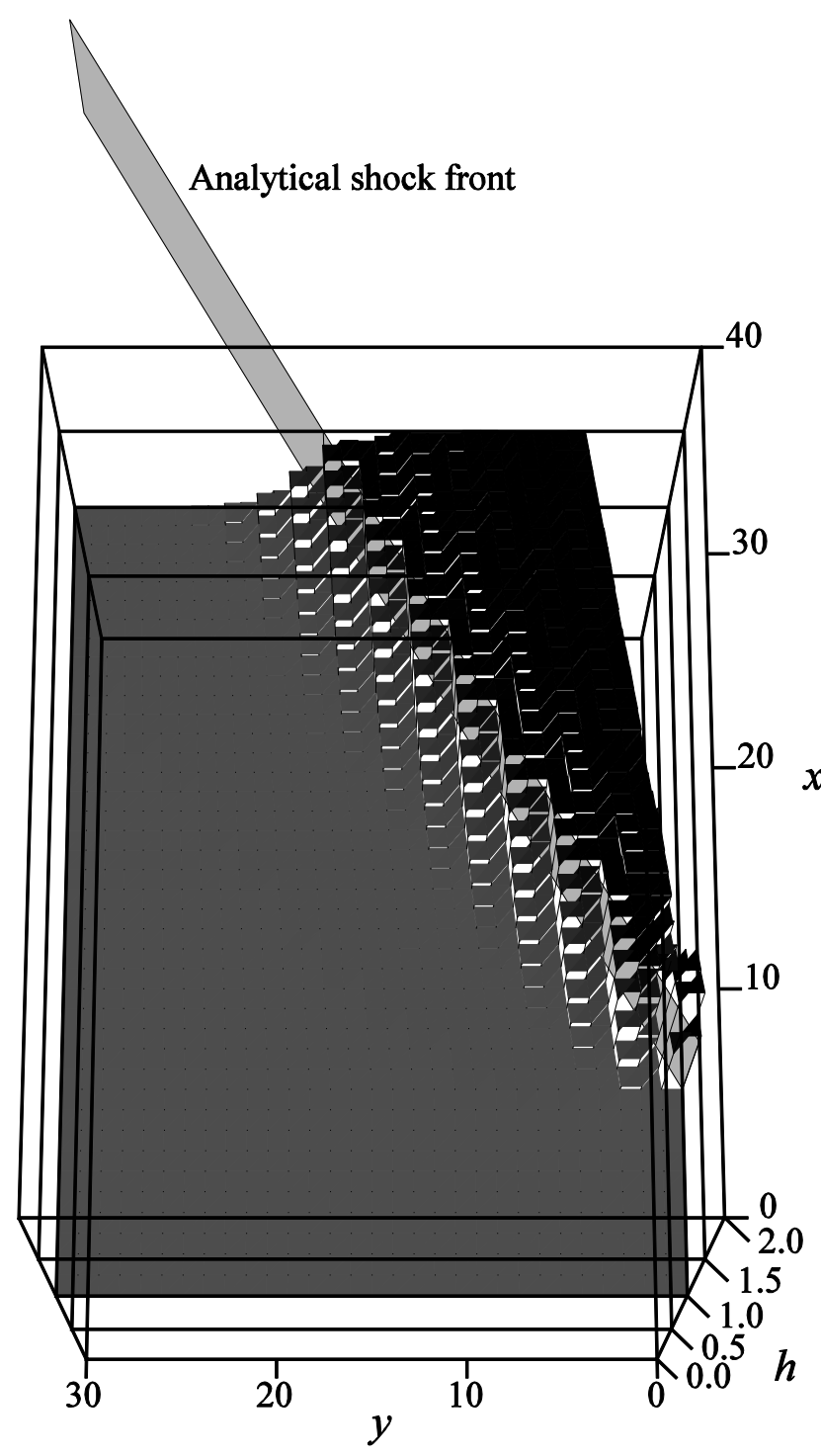

Fig. 3. Perspective view of oblique hydraulic jump 


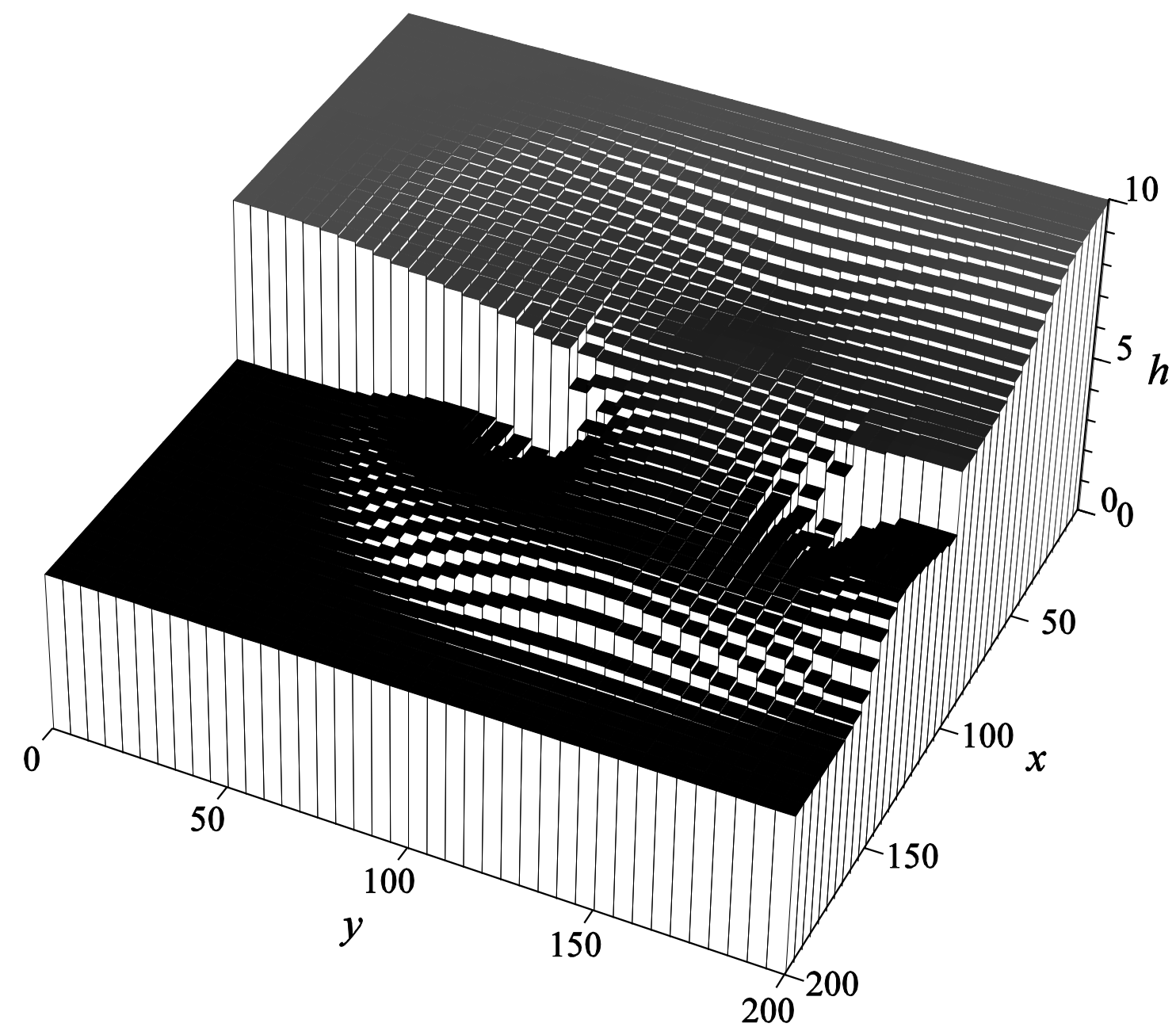

Fig. 4. Perspective view of 2D dam-break flow at $t=7.2$ by Godunov-type scheme 


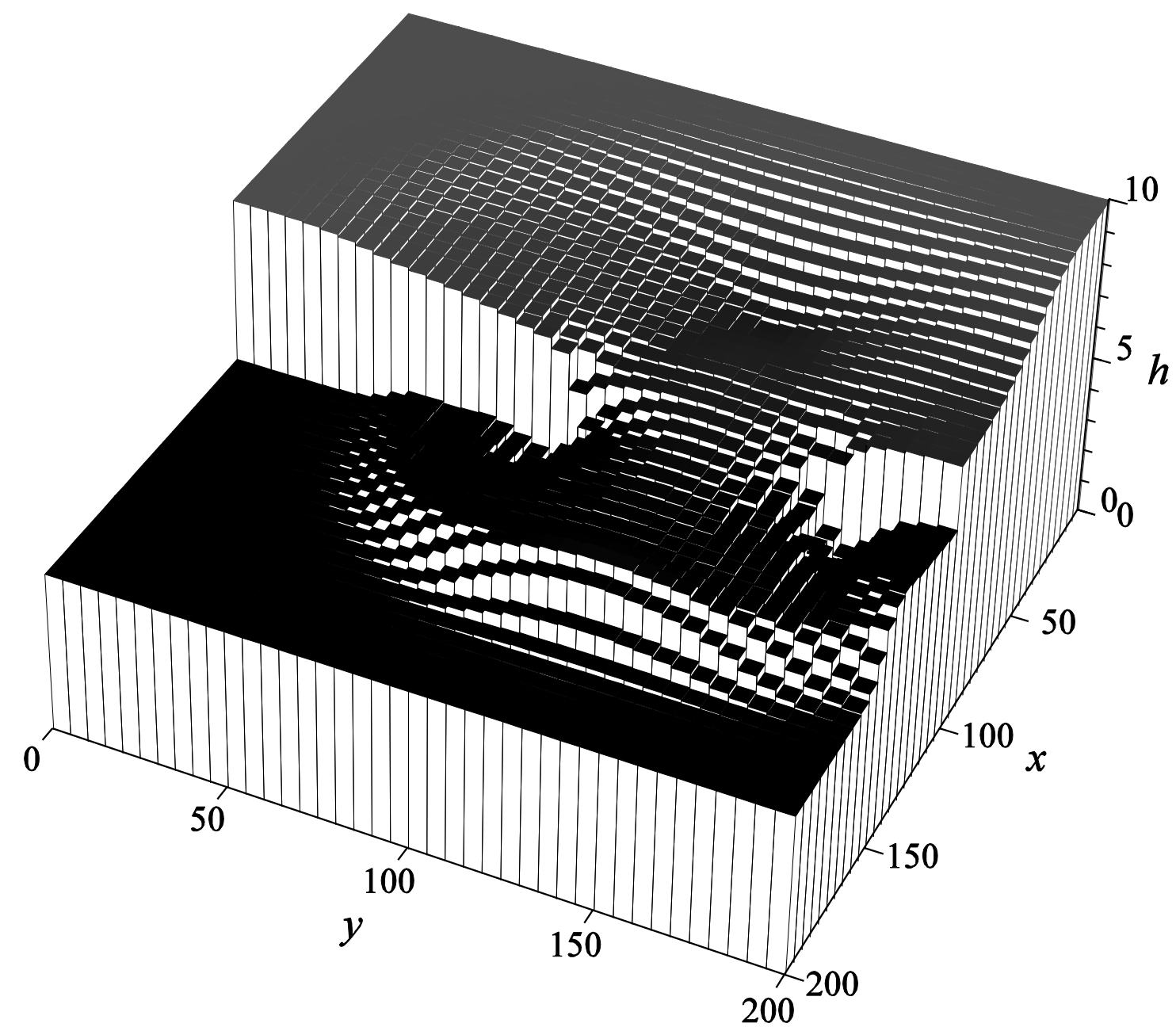

Fig. 5. Perspective view of $2 \mathrm{D}$ dam-break flow at $t=7.2$ by proposed scheme 


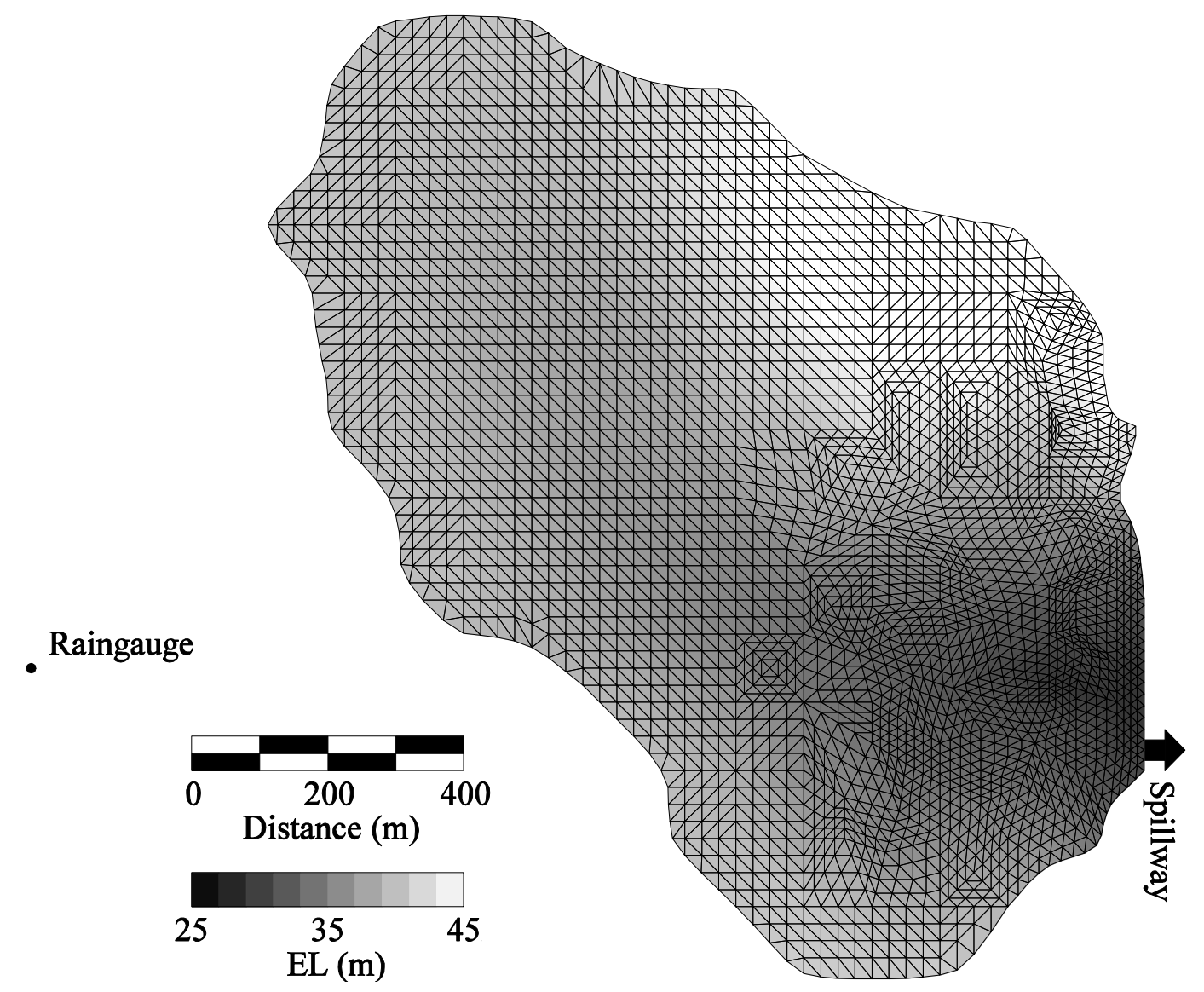

Fig. 6. Discretized domain of calibration watershed 


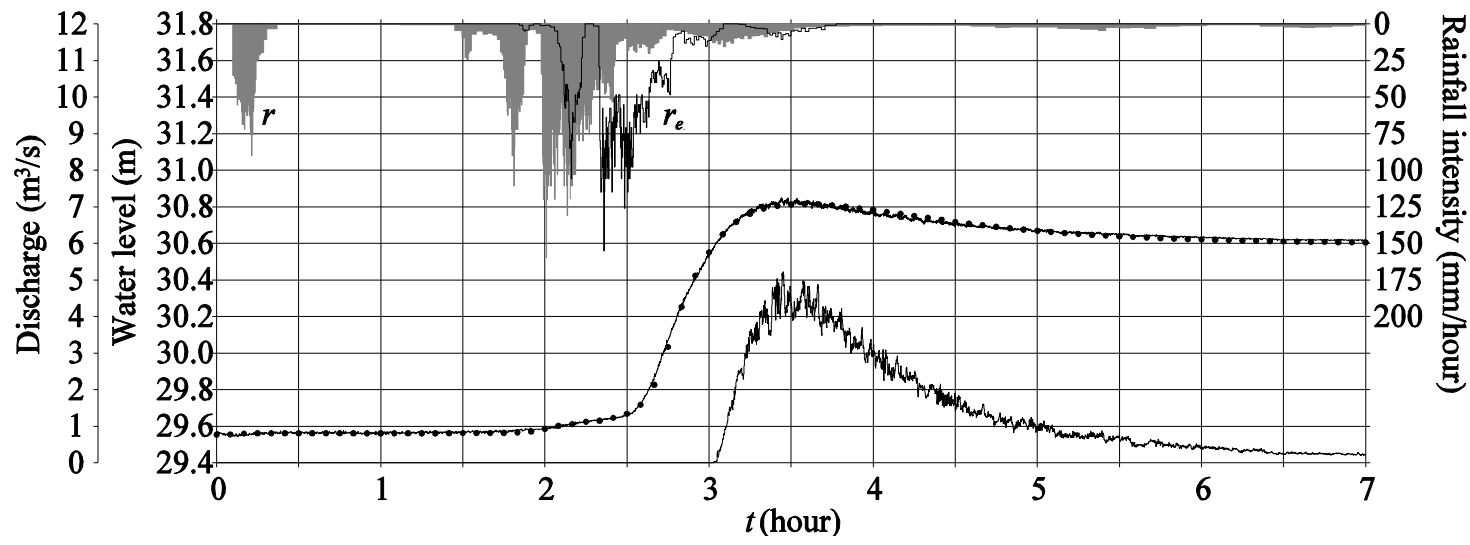

Fig. 7. Hyetograph, dam water level, and overflow discharge from spillway 


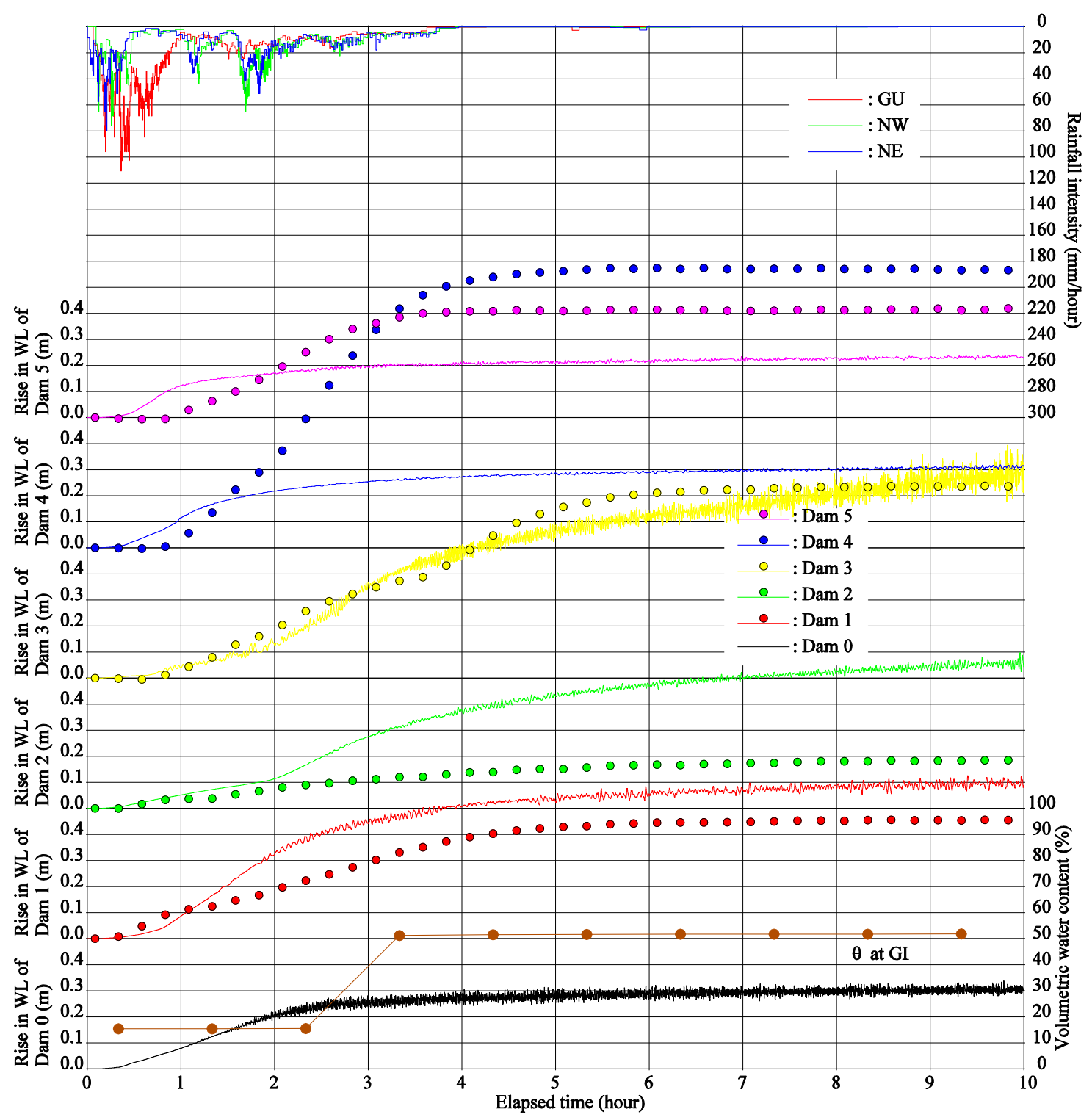

Fig. 8. Results of observation and simulation for May 14, 2007 


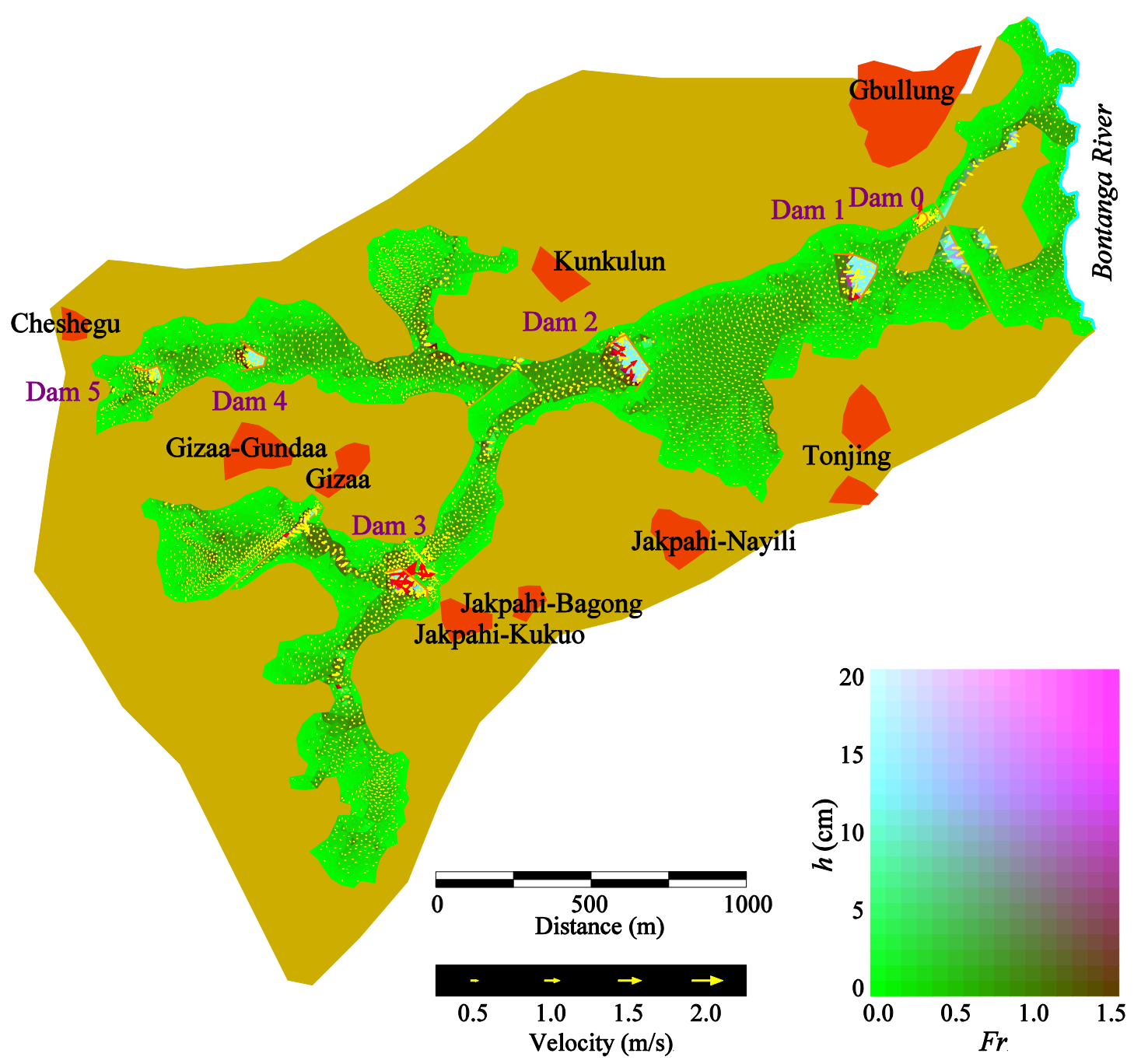

Fig. 9. Computed flow fields at $t=10$ hours when runoff process is completed 


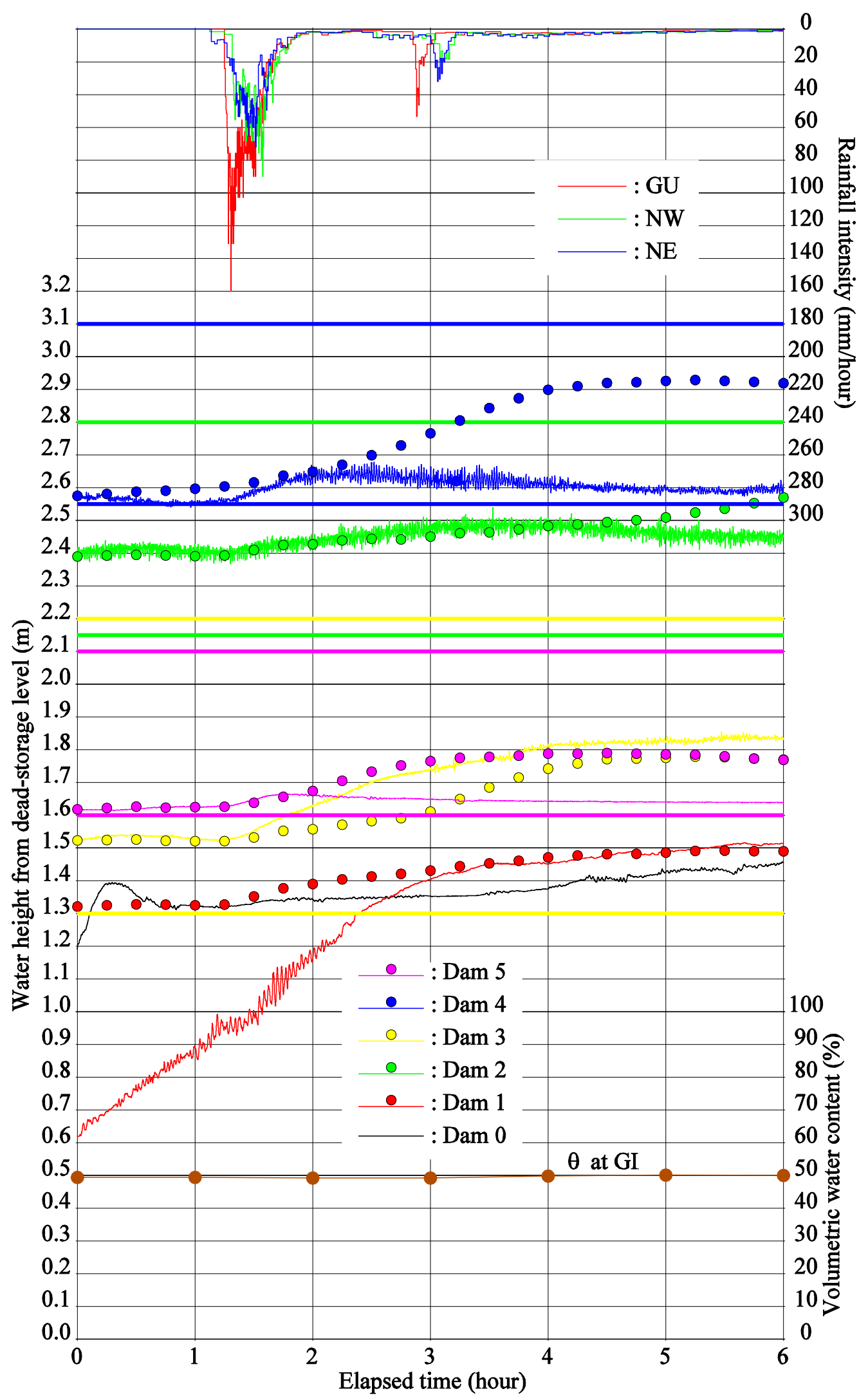

Fig. 10. Results of observation and simulation with $k_{H}=0.005 \mathrm{~m} / \mathrm{s}$ for September 18-19, 2007 


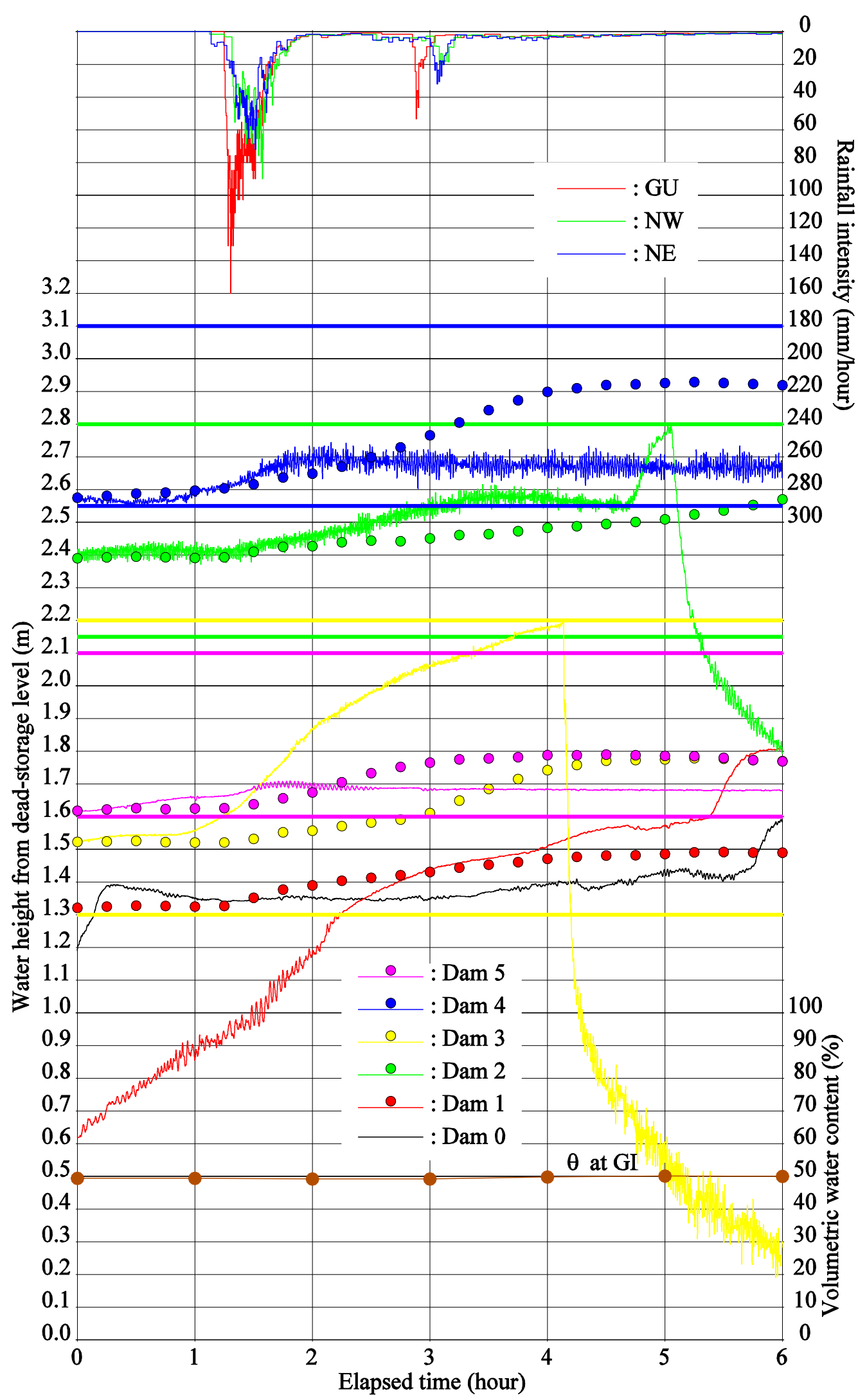

Fig. 11. Results of observation and simulation with $k_{H}=0.010 \mathrm{~m} / \mathrm{s}$ for September 18-19, 2007 


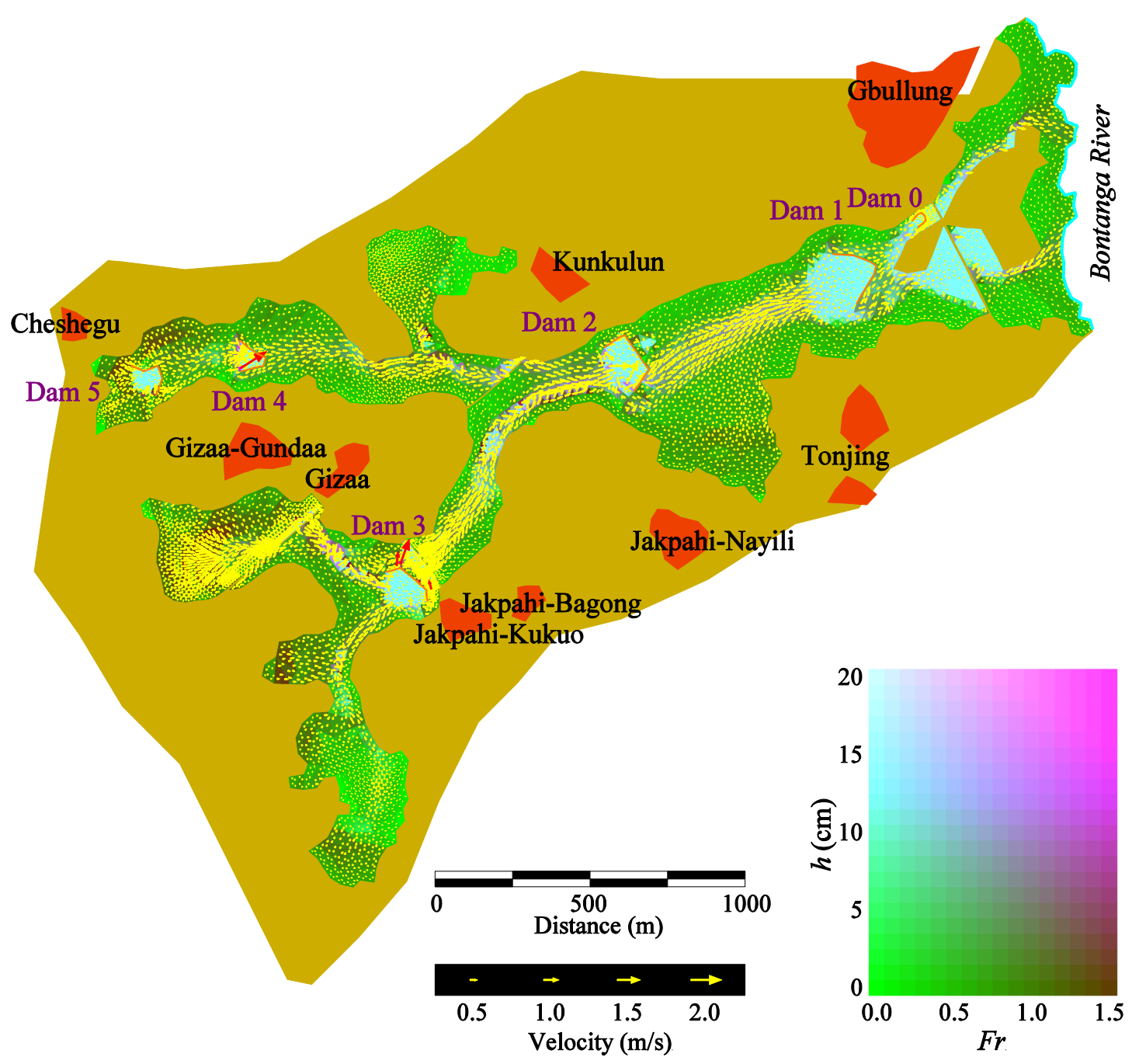

Fig. 12. Computed flow fields at $t=4.00$ hours before breaching of dams 


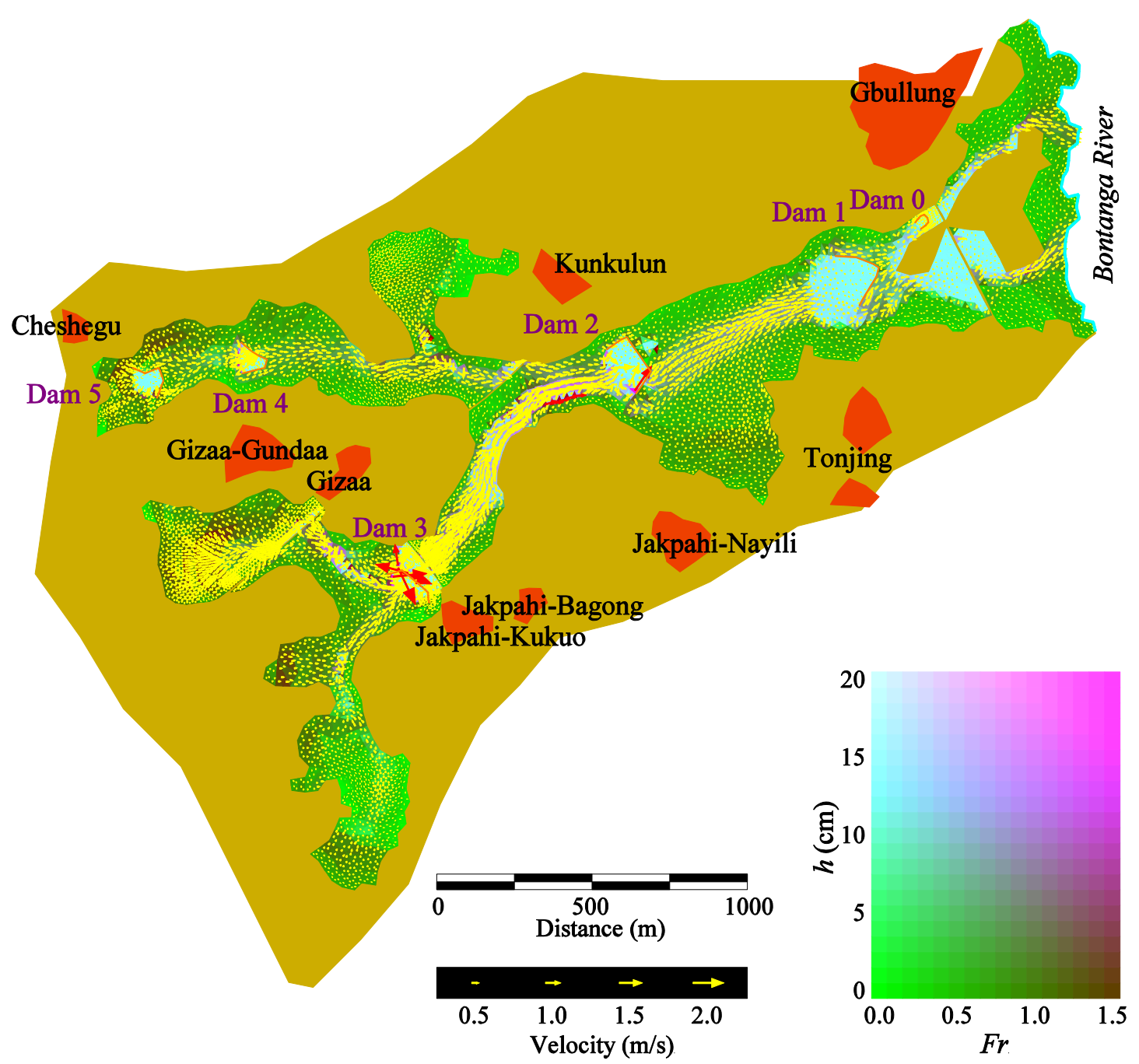

Fig. 13. Computed flow fields at $t=4.67$ hours when a surge propagating from Dam 3 to Dam 2 


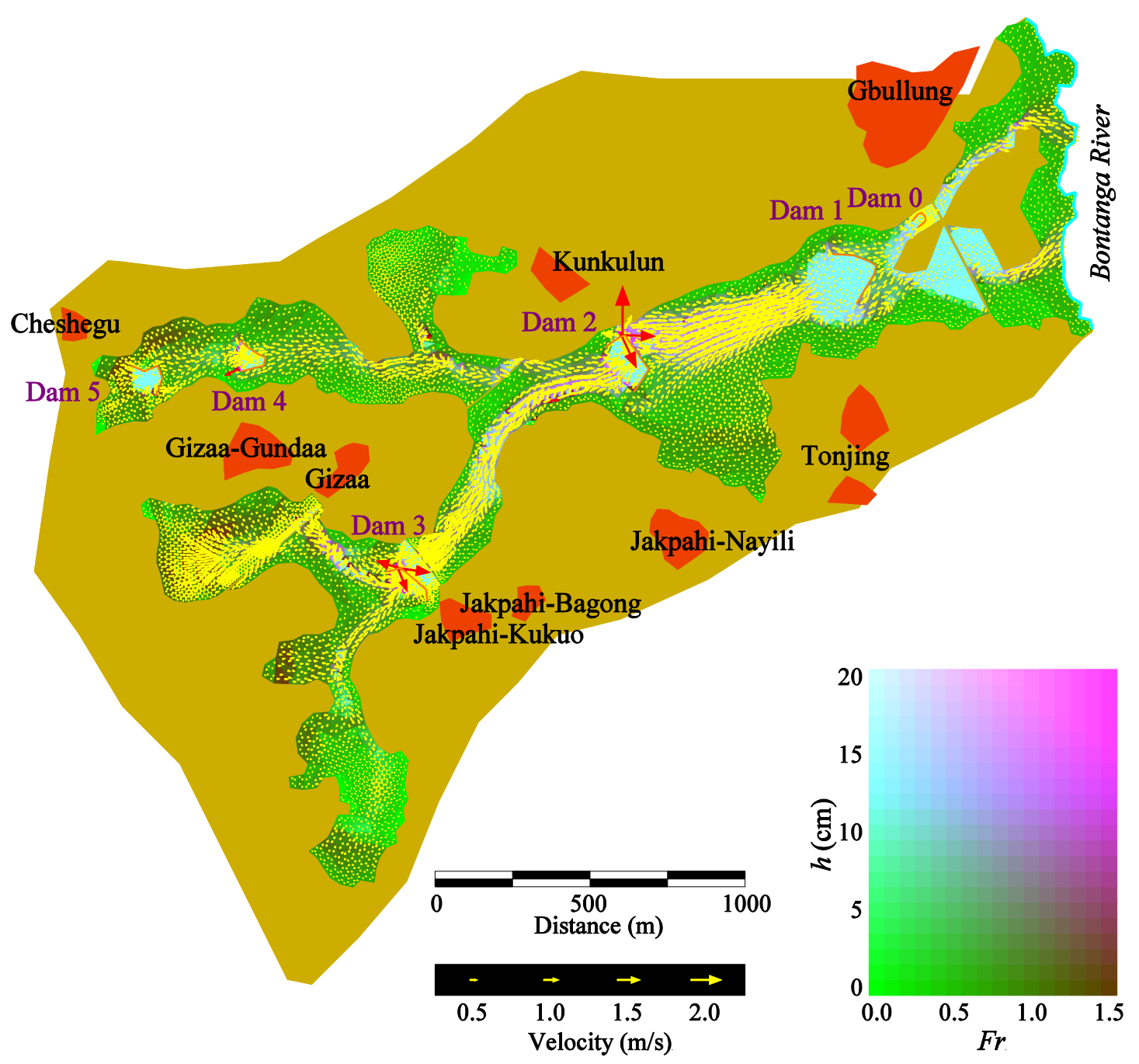

Fig. 14. Computed flow fields at $t=5.33$ hours after breaching of two dams 


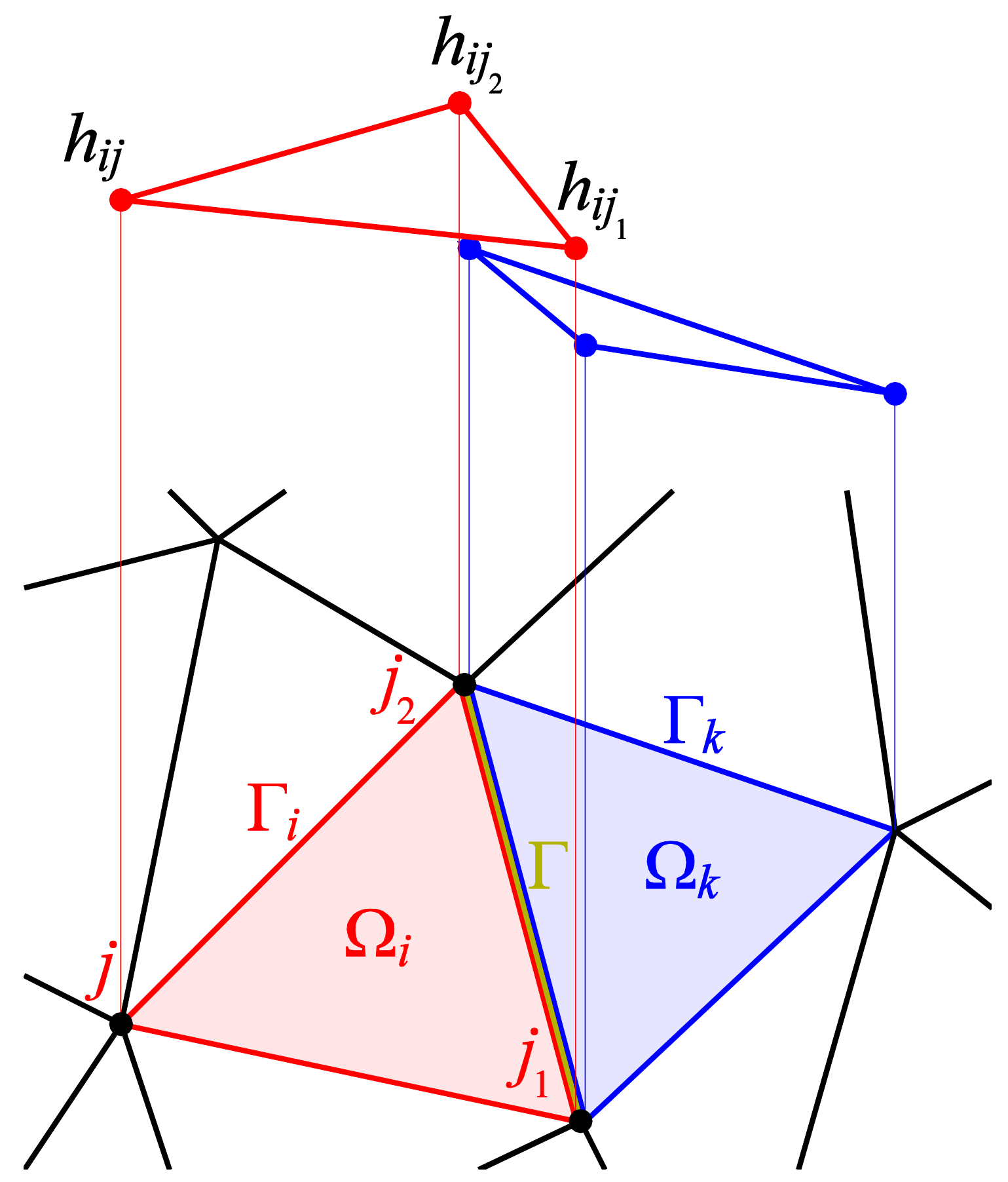

Fig. 15. Cells and vertices concerning flux splitting scheme 